\title{
Evidence of Effectiveness of Herbal Medicinal Products in the Treatment of Arthritis
}

\author{
Part 2: Rheumatoid Arthritis
}

\author{
Melainie Cameron ${ }^{1,2}$, Joel J. Gagnier ${ }^{3}$, Christine V. Little ${ }^{4}$, Tessa J. Parsons ${ }^{5}$, Anette Blümle ${ }^{6}$ \\ and Sigrun Chrubasik ${ }^{7}$ \\ ${ }^{1}$ School of Sport and Exercise Science, Centre for Ageing, Rehabilitation, Exercise and Sport (CARES), Victoria University, \\ Melbourne, Australia. \\ ${ }^{2}$ School of Exercise Science, Australian Catholic University, Banyo, Brisbane, Australia. \\ ${ }^{3}$ Department of Epidemiology, School of Public Health, University of Michigan, Ann Arbor, MI, USA. \\ ${ }^{4}$ School of Health \& Social Care, Bournemouth University, UK. \\ ${ }^{5}$ Centre for Paediatric Epidemiology \& Biostatistics, UCL Institute of Child Health, London, UK \\ ${ }^{6}$ German Cochrane Centre, Department of Medical Biometry \& Statistics, University Medical Center Freiburg, Germany. \\ ${ }^{7}$ Institute of Forensic Medicine, University of Freiburg, Germany.
}

\begin{abstract}
Herbal medicinal products (HMPs) that interact with the mediators of inflammation are used in the treatment of rheumatoid arthritis (RA). The aim of this study was to update a previous systematic review published in 2000. We searched electronic databases (MEDLINE, EMBASE, CISCOM, AMED, CINAHL, Cochrane registers) to June 2007, unrestricted by date or language, and included randomized controlled trials that compared HMPs with inert (placebo) or active controls in patients with rheumatoid arthritis. Five reviewers contributed to data extraction. Disagreements were discussed and resolved by consensus with reference to Cochrane guidelines and advice from the Cochrane Collaboration.

Twenty studies (10 identified for this review update, and 10 of the 11 studies of the original review) investigating 14 HMPs were included. Meta-analysis was restricted to data from previous seven studies with oils from borage, blackcurrant and evening primrose containing gamma linolenic acid (GLA). GLA doses equal or higher than $1400 \mathrm{mg} /$ day showed benefit in the alleviation of rheumatic complaints whereas lower doses $(\sim 500 \mathrm{mg})$ were ineffective. Three studies compared products from Tripterygium wilfordii (thunder god vine) to placebos and returned favorable results but data could not be pooled because the interventions and measures differed. Serious adverse effects occurred in one study. In a follow-up study all side effects were mild to moderate and resolved after the intervention ceased, but time to resolution was variable. Two studies comparing Phytodolor $\mathbf{N}^{\mathrm{R}}$ to placebo were of limited use because some measures were poorly defined. The remaining studies, each considering differing HMPs, were assessed individually.

For most HMPs used in the treatment of RA, the evidence of effectiveness was insufficient to either recommend or discourage their use. Interventions with HMPs containing GLA or Tripterygium wilfordii extract appear to produce therapeutic effects but further investigations are warranted to prove their effectiveness and safety. Copyright @ 2009 John Wiley \& Sons, Ltd.
\end{abstract}

Keywords: Herbal therapy; osteoarthritis; Clinical trials; effectiveness; Cochrane review.

\section{INTRODUCTION}

The American College of Rheumatology (ACR) has published recommendations for the medical management of rheumatoid arthritis (RA; ACR, 2002). Ultimate management goals are 'to prevent or control of joint damage, prevent loss of function, and decrease pain'. Nonsteroidal anti-inflammatory drugs (NSAIDs), glucocorticoid joint injection, and low-dose prednisone are recommended for symptom control. Also advised is that the majority of patients with newly diagnosed RA commence disease-modifying antirheumatic drug (DMARD) therapy within three months of diagnosis, together with patient education (e.g., Arthritis Self-

* Correspondence to: Melainie Cameron, School of Exercise Science, Australian Catholic University, PO Box 456, Virginia, QLD, 4014, Australia.

E-mail: melainie.cameron@acu.edu.au
Management Program; Lorig and Holman, 1989), and physical and occupational therapies. Herbal medicinal products (HMPs) are not among the options recommended.

Later in the guidelines, the authors argue that 'given the chronic waxing and waning course of RA, a longitudinal treatment plan needs to be developed, and the patient should be involved in developing the plan. The discussion should address disease prognosis and treatment options, taking into account the costs, adverse effects, expected time for response, the patient's risk factors and co-morbid conditions, monitoring requirements of pharmacologic agents, and the patient's preferences. Expectations for treatment and potential barriers to carrying out the recommendations should be discussed.' (ACR, 2002). This charge to include the patient in care planning and to consider the patient's concerns and preferences may be viewed as a case for considering the use of herbal therapies in the treatment 
schedule of RA since many patients of rheumatologists use complementary or alternative medicines (CAM), and under-report use of these therapies to medical practitioners (Cronan et al., 1989; Boisset and Fitzcharles, 1994; Buchbinder et al., 2002). Patients' reasons for using CAM include: (1) dissatisfaction with conventional treatment; (2) a need to control their own health care; (3) agreement with the philosophy and ideas of alternative therapies (Astin, 1998); and (4) desire to avoid side effects of conventional therapies (Ernst et al., 1995). Whereas in Chinese medicine 'Lei Gong Teng' (thunder god vine or 'three-wing nut') has been used for centuries to treat inflammatory tissue swelling (MacPherson and Blackwell, 1994), most popular antirheumatic remedies in European include preparations from the bark of Salix species, the root of devil's claw (Harpagophytum procumbens) and the aerial parts of nettle (Urtica dioica) (Chrubasik and Wink, 1998; Chrubasik and Eisenberg, 1998).

RA is a systemic inflammatory disorder that affects approximately $1 \%$ of the population worldwide, more females than males. Its predominant symptoms include pain, stiffness, and swelling of peripheral joints. RA may be mild and self-limiting, but in other cases may rapidly progress into a multisystem inflammation with irreversible joint destruction and increased risk of mortality. Negative prognostic factors for severity include presence of rheumatoid factor or HLADR4 alleles, early development of joint erosions, increasing number of affected joints, early disability, older age at onset, fewer years of formal education, and presence of extraarticular features. Synovial inflammation, cartilage destruction, and bone erosions characterise the pathophysiological joint processes of RA in which several proinflammatory pathways are involved (Lee and Weinblatt, 2001). Tumor necrosis factor alpha (TNF $\alpha$ ), interleukin 1 (IL-1), interleukin 6 (IL-6), and receptor activator of nuclear factor kappa-B ligand (RANKL) play central roles in synovitis and joint destruction. For example, increased expression of IL- 1 and TNF $\alpha$ results in inhibition of bone formation via the stimulation of nitric oxide production in osteoblasts; increased IL-6 expression accelerates bone resorption. RANKL activates osteoclasts via receptor factor kappa-B (RANK), the receptor for RANKL on the osteoclast surface. Activated metalloproteinases and neutral proteases degrade structural proteins of the extracellular matrix. Activated $\mathrm{T}$ cells, chemokines, adhesion molecules angiogenetic cytokines, growth factors and colonystimulating factors, as well as cyclooxygenase (COX) and lipoxygenase (LOX) also participate in the inflammatory process (O'Gradaigh et al., 2004).

From in vitro research it seems likely, that HMPs interact with inflammation and cytokine-induced damage. Although the exact mechanisms of action have not yet been elucidated, there is no doubt that all plant materials act via several pathways (some not yet identified), including inhibition of COX and/or LOX, inhibition of cytokine release, inhibition of elastase or hyaluronidase besides exerting antioxidative activity (Chrubasik et al., 2007; for further details see Tables 1a and 1b). Capsaicin has a different mode of action; it alters synthesis, storage, transport, and release of substance P (Buck and Burks, 1986) and thus, the transmission of pain, stimulates vanilloid receptors (Dedov and Roufogalis, 2000), and also destroys reversibly the fine nerve endings (Nolano et al., 1999) as well as inhibiting LOX (Flynn et al., 1986).

The aim of this review was to update an existing systematic review on the effectiveness of HPMs in the treatment of rheumatoid arthritis (Little and Parsons, 2000) by adding data from relevant randomized controlled trials published in the period from January 2000 to June 2007.

\section{METHODS}

All randomized controlled (placebo or active control) parallel and crossover trials examining the effects of herbal interventions for treating rheumatoid arthritis were included if patients were diagnosed with rheumatoid arthritis according to American College of Rheumatology (ACR) criteria (Arnett et al., 1988). Studies with samples defined according to vague descriptions (e.g., 'joint pain') were not considered.

Any form of herbal intervention compared with an inert (placebo) or active control, via any route of administration, was included. Herbal therapy used in conjunction with other treatments or combined with a non-herbal substance were also included if the effect of the non-herbal intervention was: (1) consistent among all groups; and (2) quantifiable. Herbal intervention included any plant preparation (crude plant material, powder, extract, mixture) but excluded homeopathy, aromatherapy, or any preparation of synthetic origin.

Primary outcomes included: changes in assessed clinical measures of effectiveness (e.g., mobility, grip strength), changes in self-reported measures of effectiveness (e.g., pain, use of medication), any adverse reaction $(\mathrm{AE})$. Secondary outcomes included: quality of life indicators, satisfaction.

We searched the following electronic databases (from 1966): Cochrane Musculoskeletal Group Register; Cochrane Complementary Medicine Field Register; Cochrane Controlled Trials Register (CCTR); MEDLINE; EMBASE; CISCOM; AMED; CINAHL; Dissertation Abstracts; BIDS ISI. Thesaurus and free text searches were performed across each database to combine the terms arthritis and herbal medicine. The general structure of the search strategy was arthritis (or synonyms) and herb (or synonyms). No methodological filter was applied and the search was not limited by language.

The following keywords were applied: arthritis, rheumatoid arthritis, reactive arthritis, adjuvant arthritis, infective arthritis, osteoarthritis, gouty arthritis, juvenile rheumatoid arthritis, psoriatic arthritis, periarthritis. Free text search terms included arthrit* and also combined the terms hip, knee, joint, musculoskeletal and pain, inflammation, movement, stiffness, medicine herbal, medicines herbal, herbal medicine, drugs Chinese herbal, plants medicinal. Free text search terms included herb* or plant*. On completion of the primary search, a secondary search combined the terms arthritis (or synonym) and each named herb.

All titles and abstracts identified from electronic databases and other searches were independently examined by two investigators (CL, MC). A full manuscript was retrieved for each record that had the possibility of meeting the review criteria. Three reviewers (CL, MC, 
Table 1a. Effect mechanisms suggested from in vitro studies (GLA gamma-linolenic acid)

\begin{tabular}{|c|c|c|c|c|c|c|}
\hline \multirow[b]{2}{*}{ Plant Name } & \multicolumn{5}{|l|}{ Inhibition of } & \multirow[b]{2}{*}{$\begin{array}{l}\text { Antioxidative } \\
\text { Effect }\end{array}$} \\
\hline & $\operatorname{cox}-1$ & $\mathrm{COX}-2$ & LOX & Cytokines & $\begin{array}{l}\text { Elastase* }^{*} \\
\text { Hyaluronidase }\end{array}$ & \\
\hline $\begin{array}{l}\text { Phytodolor } \\
\text { Herbal mixture }\end{array}$ & $\begin{array}{l}\text { not } \\
\quad \text { investigated }\end{array}$ & Schaser et al., 2006 & $\begin{array}{l}\text { Meyer et al., } \\
1995\end{array}$ & $\begin{array}{l}\text { Schaser et al., } \\
2006\end{array}$ & $\begin{array}{l}\text { *Von } \\
\text { Kruedener } \\
\text { et al., } 1996\end{array}$ & $\begin{array}{l}\text { Strehl et al., } 1995 \\
\text { Meyer et al., } 1995 \\
\text { Hartwich et al., } \\
2006 \\
\text { Rohnert et al., } \\
\text { 1998a,b }\end{array}$ \\
\hline $\begin{array}{l}\text { SKI 306X } \\
\text { Herbal mixture }\end{array}$ & $\begin{array}{l}\text { not } \\
\text { investigated }\end{array}$ & Kim et al., 2005a & $\begin{array}{l}\text { Kim et al., } \\
2005 a\end{array}$ & $\begin{array}{l}\text { Kim et al., 2005a,b } \\
\text { Choi et al., } 2002\end{array}$ & $\begin{array}{l}\text { not } \\
\text { investigated }\end{array}$ & Kim et al., 2005a \\
\hline Salix species & $\begin{array}{l}\text { Khayyal et al., } \\
2005\end{array}$ & $\begin{array}{l}\text { Fiebich \& } \\
\quad \text { Chrubasik, } 2004 \\
\text { Khayyal et al., } 2005\end{array}$ & $\begin{array}{l}\text { Wurm et al., } \\
1982 \\
\text { Khayyal et al., } \\
2005\end{array}$ & $\begin{array}{l}\text { Fiebich \& } \\
\text { Chrubasik, } 2004 \\
\text { Khayyal et al., } \\
2005\end{array}$ & $\begin{array}{l}\text { Kuppsamy } \\
\text { et al., } 1990\end{array}$ & $\begin{array}{l}\text { Kahkonen et al., } \\
1999 \\
\text { Rohnert et al., } \\
\text { 1998a,b } \\
\text { Khayyal et al., } \\
2005\end{array}$ \\
\hline $\begin{array}{l}\text { Uncaria } \\
\text { species* }\end{array}$ & $\begin{array}{l}\text { Aguilar } \\
\quad \text { et al., } 2002\end{array}$ & Aguilar et al., 2002 & $\begin{array}{l}\text { not } \\
\quad \text { investigated }\end{array}$ & $\begin{array}{l}\text { Sandoval et al., } \\
\text { 2000; } 2002 \\
\text { Allen-Hall et al., } \\
2007 \\
\text { Aguilar et al., } 2002 \\
\text { Miller et al., } 2006\end{array}$ & $\begin{array}{l}\text { not } \\
\quad \text { investigated }\end{array}$ & $\begin{array}{l}\text { Sandoval et al., } \\
\text { 2000; } 2002 \\
\text { Goncalves et al., } \\
2005 \\
\text { Pilarski, } 2006\end{array}$ \\
\hline $\begin{array}{l}\text { Tripterygium } \\
\text { wilfordii }\end{array}$ & $\begin{array}{l}\text { Zong et al., } \\
2004 \\
\text { Li et al., } 2003 \\
\text { Chou \& } \\
\text { Chang, } 1998\end{array}$ & $\begin{array}{l}\text { Tao et al., } 1998 \\
\text { Liu et al., } 2007 \\
\text { Lin et al., } 2007 \\
\text { Zou et al., } 2007 \\
\text { Li et al., } 2003 \\
\text { Maekawa et al., } \\
\quad 1999 \\
\text { Tao et al., } 1998\end{array}$ & Li et al., 2003 & $\begin{array}{l}\text { Chang et al., } 1997 \\
\text { Ho et al., 1999 } \\
\text { Lin et al., 2001; } \\
2007 \\
\text { Zou et al., } 2007 \\
\text { Chou and Chang, } \\
1998\end{array}$ & & $\begin{array}{l}\text { Wu et al., } 2006 \\
\text { Kim et al., } 2004 \\
\text { Guo et al., } 2001 \\
\text { Wang et al., } 2004\end{array}$ \\
\hline $\begin{array}{l}\text { Seed oils with } \\
\text { GLA }\end{array}$ & $\begin{array}{l}\text { Iverson et al., } \\
1992\end{array}$ & not investigated & $\begin{array}{l}\text { Iverson et al., } \\
1992 \\
\text { Ziboh et al., } \\
2004 \\
\text { Ziboh \& } \\
\quad \text { Fletcher, } 1992 \\
\text { Chilton et al., } \\
1996\end{array}$ & $\begin{array}{l}\text { DeLuca et al., } \\
1999 \\
\text { Furse et al., 2001, } \\
2002 \\
\text { Dooper et al., } \\
2003 \\
\text { Santoli et al., } 1989 \\
\text { Purasiri et al., } \\
1997\end{array}$ & $\begin{array}{l}\text { not } \\
\quad \text { investigated }\end{array}$ & Jiang et al., 1996 \\
\hline $\begin{array}{c}\text { Boswellia } \\
\text { serrata }\end{array}$ & $\begin{array}{l}\text { Siemoneit } \\
\text { et al., } 2007\end{array}$ & $\begin{array}{l}\text { no activity } \\
\text { Ammon et al.,1993 } \\
\text { Siemoneit et al., } \\
2007\end{array}$ & $\begin{array}{l}\text { Ammon et al., } \\
\text { 1991; } 1993 \\
\text { Poeckel et al., } \\
2006 \\
\text { Wildfeuer et al., } \\
1998\end{array}$ & $\begin{array}{l}\text { Roy et al., 2005; } \\
2006 \\
\text { Takada et al., } 2006 \\
\text { Gayathri et al., } \\
2007 \\
\text { Chevrier et al., } \\
2005\end{array}$ & $\begin{array}{l}\text { Safayhi et al., } \\
1997\end{array}$ & $\begin{array}{l}\text { pro-oxidative } \\
\text { Altman et al., } \\
2004 \\
\text { Glaser et al., } \\
1999 \\
\text { anti-oxidative } \\
\text { Gayathri et al., } \\
2007\end{array}$ \\
\hline $\begin{array}{l}\text { Tanacetum } \\
\text { parthenium }\end{array}$ & $\begin{array}{l}\text { Sumner et al., } \\
1992 \\
\text { Capasso, } 1986 \\
\text { Pugh and } \\
\text { Sambo } 1988 \\
\text { Collier et al., } \\
1980 \\
\text { Williams et al., } \\
1999\end{array}$ & Hwang et al., 1996 & $\begin{array}{l}\text { Sumner et al., } \\
\quad 1992 \\
\text { Capasso, } 1986 \\
\text { Williams et al., } \\
1999\end{array}$ & $\begin{array}{l}\text { Piela-Smith et al., } \\
2001 \\
\text { Hwang et al., } 1996 \\
\text { Smolinski \& } \\
\text { Peska, 2003 } \\
\text { Saadane et al., } \\
2007 \\
\text { Kwok et al., } 2001 \\
\text { Li-Weber et al., } \\
2002 \\
\text { Kang et al., } 2001\end{array}$ & $\begin{array}{l}\text { *Siedle et al., } \\
2003\end{array}$ & $\begin{array}{l}\text { Fukuda et al., } \\
2000\end{array}$ \\
\hline
\end{tabular}

* interaction with 5-HT2 receptors (Jürgensen et al., 2005); * interaction with 5-HT2 receptors (Mittra, 2000). 
Table 1b. Cytokine inhibition suggested from in vitro studies (GLA gamma-linolenic acid)

\begin{tabular}{|c|c|c|c|c|c|}
\hline \multirow[b]{2}{*}{ Plant Name } & \multicolumn{5}{|l|}{ Inhibition of Cytokines } \\
\hline & Interleukin-1 $\beta$ & TNF- $\alpha$ & $N F-\kappa B$ & MMPs & Others \\
\hline $\begin{array}{l}\text { Phytodolor } \\
\text { Herbal } \\
\quad \text { mixture }\end{array}$ & Schaser et al., 2006 & not investigated & not investigated & not investigated & not investigated \\
\hline $\begin{array}{l}\text { SKI } 306 X \\
\text { Herbal } \\
\quad \text { mixture }\end{array}$ & $\begin{array}{l}\text { no effect } \\
\text { Kim et al., 2005a }\end{array}$ & Kim et al., 2005a & not investigated & Kim et al., 2005b & Choi et al., 2002 \\
\hline Salix species & $\begin{array}{l}\text { Fiebich \& Chrubasik, } \\
2004 \\
\text { Khayyal et al., } 2005\end{array}$ & $\begin{array}{l}\text { Khayyal et al., } \\
2005\end{array}$ & not investigated & not investigated & Khayyal et al., 2005 \\
\hline $\begin{array}{l}\text { Uncaria } \\
\text { species }\end{array}$ & Allen-Hall et al., 2007 & $\begin{array}{l}\text { Sandoval et al., } \\
2000 \\
\text { Sandoval et al., } \\
2002 \\
\text { Allen-Hall et al., } \\
2007\end{array}$ & Aguilar et al.,2002 & & Miller et al., 2006 \\
\hline $\begin{array}{l}\text { Tripterygium } \\
\text { wilfordii }\end{array}$ & $\begin{array}{l}\text { Chang et al., } 1997 \\
\text { Lin et al., } 2007 \\
\text { Zou et al., } 2007 \\
\text { Maekawa et al., } 1999 \\
\text { Wu et al., } 2006\end{array}$ & $\begin{array}{l}\text { Chang et al., } 1997 \\
\text { Lin et al., } 2007 \\
\text { Zou et al., } 2007 \\
\text { Wu et al., } 2006\end{array}$ & $\begin{array}{l}\text { Sethi et al., } 2007 \\
\text { Zou et al., } 2007 \\
\text { Wu et al., } 2006 \\
\text { Kim et al., } 2004\end{array}$ & Lin et al., 2001;2007 & $\begin{array}{l}\text { Chang et al., } 1997 \\
\text { Tao et al., 1998 } \\
\text { Lin et al., 2001;2007 } \\
\text { Zou et al., 2007 } \\
\text { Wu et al., } 2006\end{array}$ \\
\hline $\begin{array}{l}\text { Seed oils } \\
\text { with GLA }\end{array}$ & $\begin{array}{l}\text { Furse et al., 2001, } 2002 \\
\text { DeLuca et al., } 1999 \\
\text { Dooper et al., } 2003\end{array}$ & $\begin{array}{l}\text { DeLuca et al., } 1999 \\
\text { Dooper et al., } 2003 \\
\text { Furse et al., } 2001 \\
\text { Purasiri et al., } 1997\end{array}$ & not investigated & not investigated & $\begin{array}{l}\text { Purasiri et al., } 1997 \\
\text { Santoli et al., } 1989 \\
\text { Chou and Chang, } 1998\end{array}$ \\
\hline $\begin{array}{c}\text { Boswellia } \\
\text { serrata }\end{array}$ & Gayathri et al., 2007 & $\begin{array}{l}\text { Roy et al., } 2006 \\
\text { Gayathri et al., } \\
2007\end{array}$ & Takada et al., 2006 & Roy et al., 2006 & $\begin{array}{l}\text { Roy et al., } 2005 \\
\text { Gayathri et al., } 2007 \\
\text { pro-inflammatory } \\
\text { Khajuria et al., } 2008 \\
\text { Chevrier et al., } 2005\end{array}$ \\
\hline $\begin{array}{l}\text { Tanacetum } \\
\text { parthenium }\end{array}$ & $\begin{array}{l}\text { Piela-Smith et al., } 2001 \\
\text { Hwang et al., } 1996\end{array}$ & $\begin{array}{l}\text { Piela-Smith et al., } \\
2001 \\
\text { Smolinski \& Peska, } \\
2003 \\
\text { Hwang et al., } 1996\end{array}$ & $\begin{array}{l}\text { Saadane et al., } 2007 \\
\text { Kwok et al., } 2001\end{array}$ & & $\begin{array}{l}\text { Piela-Smith et al., } \\
2001 \\
\text { Saadane et al., } 2007 \\
\text { Smolinski \& Peska, } \\
2003 \\
\text { Li-Weber et al., } 2002 \\
\text { Kang et al., } 2001\end{array}$ \\
\hline
\end{tabular}

SC) independently assessed eligibility of retrieved studies for review according to the inclusion criteria. Five reviewers (MC, SC, AB, JG, TP) contributed to data extraction. Data were extracted from each eligible study by two reviewers acting independently. Where a study was defined as a crossover trial, data were extracted only up to the point of crossover in order that these data could be compared with those derived from parallel trials.

Two review authors (MC, SC) independently assessed the risk of bias of each included trial, against key criteria: random sequence generation; allocation concealment; blinding of participants, personnel and outcomes; incomplete outcome data; selective outcome reporting; and other sources of bias, in accordance with methods recommended by the Cochrane Collaboration (Higgins and Green, 2008). Each of these criteria was explicitly judged using: $\mathrm{A}=$ yes (low risk of bias); $\mathrm{B}=$ no (high risk of bias); $\mathrm{C}=$ unclear (either lack of information or uncertainty over the potential for bias). Potential disagreements were discussed and resolved by referring to the original protocol and, if necessary, arbitration by member(s) of the Cochrane Steering Group.
Descriptive results are reported for all included studies. Studies with the same outcome measures and comparators were included in the meta-analyses. For dichotomous outcomes, odds ratios or relative risks were calculated. For continuous outcomes, a mean difference (MD) was calculated and confidence intervals reported at $95 \%$. Chi-square and $\mathrm{I}^{2}$ tests of heterogeneity were conducted and fixed or random effects models were chosen appropriately. Threshold values ( $\mathrm{p}$ and $\mathrm{I}^{2}$ ) for heterogeneity were not determined a priori; rather heterogeneity was reported using both chi-squared and $\mathrm{I}^{2}$ values, with $\mathrm{I}^{2}$ of $30-60 \%$ considered to represent moderate heterogeneity, and $\mathrm{I}^{2}$ of more than $60 \%$ as substantial heterogeneity. This categorical classification was consistent with the chi-square analyses if $p=0.10$ was accepted as the arbiter of significance. Reasons for heterogeneity were explored by reviewing study designs and results. $\mathrm{I}^{2}$ values of $80 \%$ or greater were considered to represent unacceptable heterogeneity indicating that the studies could not be rationally pooled.

Main results of the review are presented in summary of findings tables, including an overall grading of the 
evidence using the GRADE approach (Schunemann et al., 2008a), and a summary of the available data on the main outcomes, as described in the Cochrane Handbook for Systematic Reviews of Interventions (Schunemann et al., 2008b). Quality of evidence for each herbal intervention is classified as High, Moderate, Low, or Very Low, as an indication of confidence in the results of studies and meta-analyses. For example, high-quality evidence is robust and further studies are very unlikely to change our confidence in the estimate of effect; conversely, low-quality evidence is open to question and further research is very likely to have an important impact on our confidence in the estimate of effect and may change the estimate.

\section{RESULTS}

From approximately 2500 citations, a total of ten new studies, including four studies published prior to 2000, were identified for inclusion in the updated review (Meier, 1987; Eberl et al., 1988; McCarthy and McCarthy 1992; Sander et al., 1998; Chopra et al., 2000; Mur et al., 2002; Tao et al., 2002; Cibere et al., 2003; Biegert et al., 2004; Song et al., 2007). These studies were added to 10 of the 11 studies included in the original review (Belch et al., 1988; Jäntti et al., 1989a; Pattrick et al., 1989; Tao et al., 1989; Brzeski et al., 1991; Deal et al., 1991; Leventhal et al., 1993; 1994; Watson et al., 1993; Zurier et al., 1996). One study included in the original review was excluded because participants with any form of arthritic disease were recruited (Mills et al., 1996). Other reasons for excluding studies were: (1) not a randomized controlled trial; (2) discussion paper; (3) full study details not available; (4) unable to identify the herbal components of the intervention; (5) case series; (6) review paper; (7) inappropriate statistical analysis; or (8) duplicate publication.

Seventeen of the studies were of parallel design (Meier, 1987; Belch et al., 1988; Eberl et al., 1988; Jäntti et al., 1989a; Pattrick et al., 1989; Brzeski et al., 1991; Deal et al., 1991; McCarthy and McCarthy, 1992; Leventhal et al., 1993; 1994; Watson et al., 1993; Sander et al., 1998; Chopra et al., 2000; Mur et al., 2002; Tao et al., 2002; Cibere et al., 2003; Biegert et al., 2004; Song et al., 2007), one used a crossover design (Tao et al., 1989) and one a partial crossover design (Zurier et al., 1996).

The 20 studies evaluated the effectiveness of 14 HMPs as listed in Table 2. Three of these were not fully characterized so that the study could not be repeated (Sander et al., 1998; Chopra et al., 2000; Cibere et al., 2003). Herbal mono-preparations for oral use included seed oils of borage, blackcurrant and evening primrose as plant sources of gamma linolenic acid (GLA) and preparations from the herb of Tanacetum parthenium (feverfew), the root of Uncaria tomentosa (cat's claw), the bark of a Salix species (willow bark), the gum resin of Boswellia serrata, and the root of Tripterygium wilfordii (thunder god vine). The latter was also administered in form of a topical product as was capsaicin in form of creams. Herbal mixtures for oral use included the Ayurvedic formula RA-1, SKI306X, and Phytodolor $\mathrm{N}^{\mathrm{R}}$.
One study (Belch et al., 1988) included three parallel arms comparing evening primrose oil, a mixture of evening primrose oil and fish oil, and placebo, but only the evening primrose oil and placebo arms were considered in this review. One study included data on patients with OA as well as RA but data were presented separately (Deal et al., 1991). Overall, the studies reported a wide variety of clinical outcomes and some studies also reported biochemical outcomes (Belch et al., 1988; Jäntti et al., 1989b; Pattrick et al., 1989; Tao et al., 1989; Leventhal et al., 1993; 1994; Watson et al., 1993; Sander et al., 1998). Only clinical outcomes were considered in this review.

Methodological quality of each study was assessed independently by two reviewers according to the criteria described in the methods (Higgins and Green, 2008; Schunemann et al., 2008a; 2008b). Quality of the included studies was variable, and should be taken into account when interpreting results. In general, methodological quality of the new studies was superior to that of the older studies, suggesting that quality of research design and reporting has improved since 2000 (Chopra et al., 2000; Biegert et al., 2004; Song et al., 2007).

Only three studies adequately met all six validity criteria and thus were at minimal risk of bias (Chopra et al., 2000; Biegert et al., 2004; Song et al., 2007). In six studies (Belch et al., 1988; Jäntti et al., 1989a; Pattrick et al., 1989; Sander et al., 1998; Mur et al., 2002; Tao et al., 2002) the method of randomization and in one study (Meier,1987) the method of double-blinding were not described, and in one study withdrawals were not reported (Cibere et al., 2003). In eight studies neither the method of randomization nor the method of doubleblinding were described (Eberl et al., 1988; Tao et al., 1989; Brzeski et al., 1991; Deal et al., 1991; Leventhal et al., 1993; 1994; Watson et al., 1993; Zurier et al., 1996).

\section{Oils containing gammalinolenic acid (GLA)}

Seven studies investigated the effects of plant sourced GLA on a total of 286 participants. Three of them investigated evening primrose seed oils (EPO; Belch et al., 1988; Jäntti et al., 1989a; Brzeski et al., 1991;), two blackcurrant seed oils (Watson et al., 1993; Leventhal et al., 1994) and two borage seed oils (Leventhal et al., 1993; Zurier et al., 1996). The approximate daily intake of GLA varied from $525 \mathrm{mg}$ (Watson et al., 1993) to $2800 \mathrm{mg}$ (Zurier et al., 1996). Although the active principle of the seed oils may be slightly different due to the oil composition, studies were considered together based on the daily quantity of gammalinolenic acid, the patients had consumed. Placebo oils included olive oil (Jäntti et al., 1989a; Brzeski et al., 1991), sunflower oil (Watson et al., 1993; Zurier et al., 1996), liquid paraffin (Belch et al., 1988), cottonseed oil (Leventhal et al., 1993), and soybean oil (Leventhal et al., 1994).

\section{Small daily GLA doses}

Three studies investigating GLA doses between $525 \mathrm{mg}$ and $540 \mathrm{mg}$ were incompletely reported and data could not be extracted (Belch et al., 1988; Brzeski et al., 1991; Watson et al., 1993). No significant improvements in the 


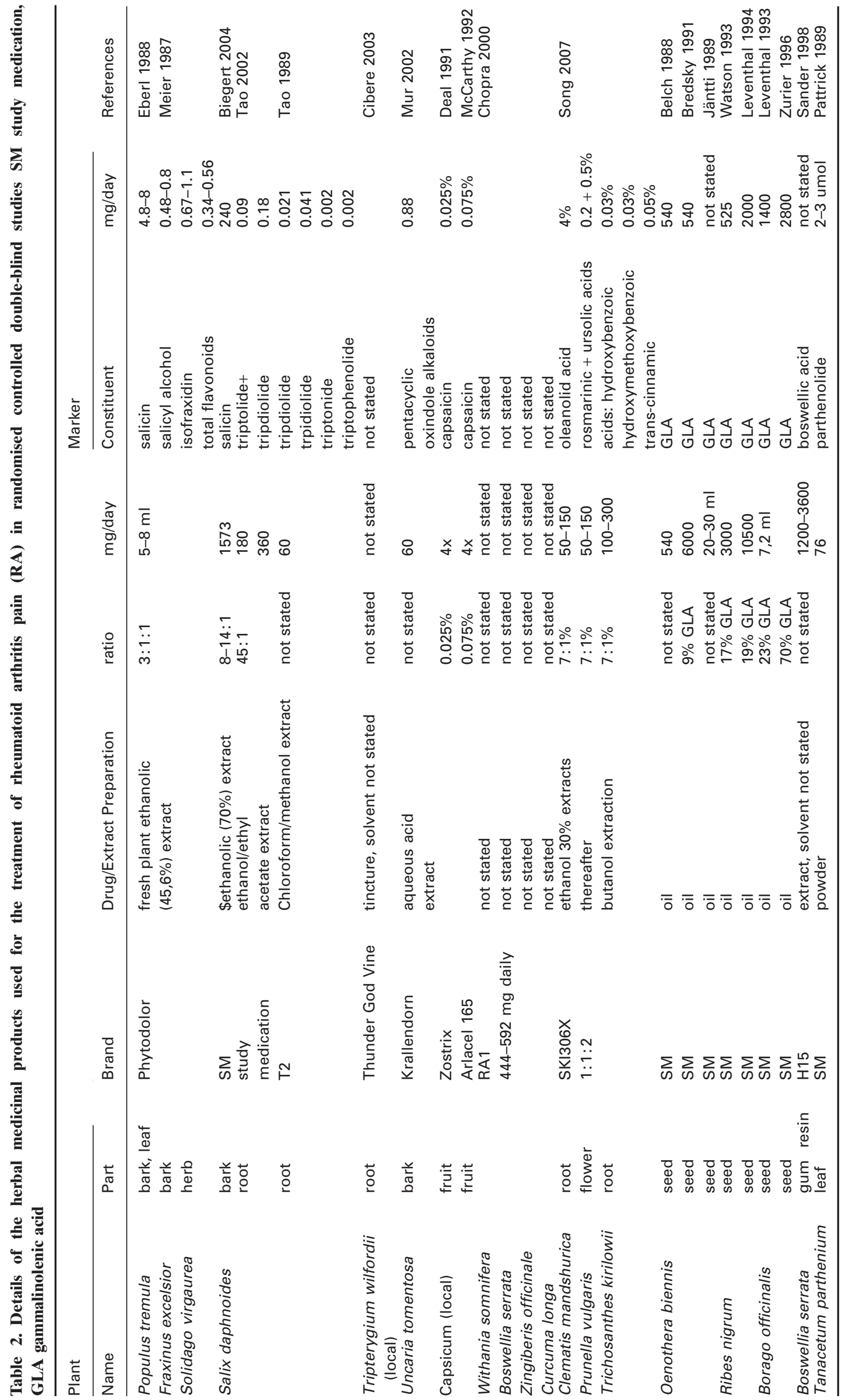


scores assessed on a visual analogue scale (VAS) were identified in any of these studies. Morning stiffness measured in minutes was significantly reduced in two studies (Brzeski et al., 1991; Watson et al., 1993). Nonsignificant trends to improvement in the Ritchie index were reported in two studies (Brzeski et al., 1991; Watson et al., 1993). Trends to reduced pain, improved grip strength and patient global assessment were also reported in one study (Watson et al., 1993). Participants' self-assessments generally favored oils containing GLA over placebo oils. An improvement in well-being was reported by almost all patients receiving blackcurrant seed oil (placebo group: 20\%; Watson, 1993). In another study, $94 \%$ of patients receiving EPO reported subjective improvement (placebo group: a little over $40 \%$ ); after a three-month placebo phase, $80 \%$ of patients taking EPO relapsed at least to their baseline parameters (placebo group 14\%; Belch et al., 1988).

In two of these studies, patients reported whether they reduced their NSAID consumption during the intervention period which lasted 6 months (Brzeski et al., 1991) or 12 months (Belch et al., 1988). These data were reported as a dichotomous variable so that the actual amount of dose reduction is unknown in most cases. In one study 11 (15) patients receiving GLA reported reduced or ceased NSAID intake compared with 5 (15) patients receiving placebo (Belch et al., 1988). In the other study, three patients in each group reported reduced NSAID intake by $400 \mathrm{mg}$ ibuprofen daily; no patient ceased NSAID use (Brzeski et al., 1991). In this study, one patient in each of the GLA and placebo groups reported increased NSAID intake (Brzeski et al., 1991). When these data are pooled, the relative risk of reducing NSAIDs is higher among patients using GLA oils than among those using placebo oils (RR 1.89 , CI 0.96 to 3.76). However, this risk estimate is drawn from studies of small sample size with incomplete data reporting, and is considered less than bronze level evidence.

Only one study included dichotomous data for patients who reported AEs: 2 (16) patients in the GLA and 0 (18) patients in the placebo group (Belch et al., 1988). The relative risk of AEs was higher in the GLA compared to the placebo group (RR 5.59, CI 0.29 to 108.38). The same study reported the number of patients who withdrew from the study due to worsening disease: GLA group 1 (16), placebo group 10 (18), relative risk of worsening disease in favor of the placebo group over the GLA group (RR 0.11, CI 0.02 to 0.78 ).

\section{Large daily dose GLA}

Four studies investigated daily GLA doses between $1400 \mathrm{mg}$ and $2800 \mathrm{mg}$, and were adequately reported to allow data extraction and some data pooling.

In the three studies, pain was assessed on a $100 \mathrm{~mm}$ VAS and reported as percentage change from baseline. Using a random effects model, pooled results showed significant improvement among patients using GLA oils compared with those using placebo oils (mean difference (MD) -32.83 , CI -56.25 to $-9.42, \mathrm{p}=0.006$ ). Although these studies applied slightly different lengths of intervention (24 weeks: Leventhal et al., 1993; 1994; 6 months: Zurier et al., 1996), results displayed little heterogeneity (chi-square 1.25, I2 =0\%, p = 0.54) and provided high-quality evidence that six months of treatment with oil containing at least $1400 \mathrm{mg}$ GLA improves self-reported pain assessed on a VAS in RA patients.

In the other study (Jäntti et al., 1989a), 100 mm VAS pain scores were reported as absolute values after 12 weeks of intervention. These results favored the placebo group with a non-significant mean difference of 6.00 (CI -16.36 to $28.36, \mathrm{p}=0.60)$. It is unclear why these results differ from those of the other three large dose studies, but possible explanations include a shorter intervention period (12 weeks), use of a non-inert oil (olive oil) in the placebo group, and a small sample size that may have contributed to Type II error.

Pain assessed on a categorical scale ( $0-4$,none to very severe) and reported as percentage change from baseline in the three longer-term studies showed near significant improvement in the GLA compared with the placebo group (MD -34.19, $\mathrm{CI}-71.57$ to $3.18, \mathrm{p}=0.07)$. These studies are moderately heterogeneous (chisquare $4.95, \mathrm{I} 2=59.6 \%, \mathrm{p}=0.08)$, but within acceptable thresholds for data pooling.

Duration of morning stiffness (MS) was measured in minutes. Absolute MS values after 12 weeks showed no improvement in the GLA versus the placebo group (MD -5.00, CI -41.68 to 31.68, p = 0.79; Jäntti et al., 1989a). Measures of MS, adjusted to change scores from baseline, were pooled for the three longer-term studies. These results favored GLA over placebo (MD -55.07, $\mathrm{CI}-76.87$ to $-33.27, \mathrm{p}<0.01$ ) and provided high-quality evidence that six months of treatment with oils containing at least $1400 \mathrm{mg}$ GLA improve self-reported duration of MS in RA patients. Given the previously mentioned caveats regarding the three-month study (Jäntti et al., 1989a), there is bronze level evidence that a shorter duration of treatment does not produce significant improvement of MS.

Tender joint count out of 68 , adjusted as a percentage change from baseline scores, reduced in favor of GLA in each of the three longer-term studies. Pooled results, using a random effects model, returned a MD of -53.80 (CI -95.61 to $-12.00, \mathrm{p}=0.01)$. These studies are substantially heterogeneous (chi-squared 6.62, I $2=69.8 \%$, $\mathrm{p}=0.04$ ), but in none of the studies the $95 \%$ confidence intervals extended to favor placebo, indicating that the findings are consistent but the overall effect $(Z=4.01)$ may be considered an estimate within a range. Likewise, pooling the data of joint tenderness assessed on a categorical scale ( $0-3$, none to severe) and presented as percentage change from baseline showed improvement in the three longer-term studies: MD -56.64 ( CI -98.10 to $-15.17, \mathrm{p}<0.01$ ). Consistent with the 68 tender joint count scores, these studies display substantial heterogeneity (chisquare $5.69, \mathrm{I} 2=64.9 \%, \mathrm{p}=0.06$ ) albeit within acceptable threshold for data pooling. The overall effect $(Z=4.06)$ should be viewed as a broad estimate of effect size. There is, thus, high-quality evidence that six months of treatment with at least $1400 \mathrm{mg}$ GLA improves joint tenderness measured either as 68 tender joint count or self-reported categorical grading of tenderness.

Swollen joint count (out of 66), adjusted as a percentage change from baseline scores, reduced in favor of GLA in two of the threee studies of approximately six months' duration (Leventhal et al., 1993; Zurier et al., 1996). In the third study (Leventhal et al., 
1994) results slightly, non-significantly, favored placebo (MD 8.00, $\mathrm{p}=0.62$ ), but this study was hampered by small sample size $(\mathrm{n}=14)$ and large variance in swollen joint count scores (CI -124.61 to 140.61). When these data were pooled, this small sample study had some influence: MD was -14.43 and the overall effect $(Z=1.66)$ was not statistically significant $(\mathrm{CI}-31.43$ to $2.56, \mathrm{p}=0.10)$. In all longerterm studies, joint swelling was also scored on a scale of 0-3 (none to severe) and converted to a percentage change from baseline measures. Consistent with the 66 swollen joint count scores, results in one of the studies (Leventhal et al., 1994) slightly favored placebo over GLA, and shifted the weighted mean to midline when data were pooled. Applying a random effects model returned a MD of -24.02 (CI -70.80 to 22.76) and a small, non-significant estimate of overall effect $(\mathrm{Z}=1.01, \mathrm{p}<0.31)$.

Six out of the seven GLA studies evaluated global impression of the intervention. All but one of these (Brzeski et al., 1991) reported that patients found the GLA oil to be superior to the placebo oil. Due to differences in scales and data reporting, only data of three studies were available for extraction and pooling (Leventhal 1993; 1994; Zurier et al., 1996). Global evaluations of disease activity by physician and patient were measured using a $0-4$ (none to very severe) scale and converted to percentage change from baseline scores. The MD for patient global evaluation was -20.87 ( CI -39.43 to -2.31 , $\mathrm{p}=$ 0.03 ), thus, providing high-quality evidence that six months of treatment with at least $1400 \mathrm{mg}$ GLA improves self-reported evaluation of disease severity over placebo among patients suffering from RA. Pooled data for physician global evaluation returned a non-significant MD of -21.28 (CI -70.52 to 27.95, $\mathrm{p}=0.40)$. Global evaluation by physician showed substantial and unacceptable heterogeneity between the studies (chi-square 11.20, I2 = 82.1\%, p < 0.01). In only one of these three studies was the procedure for physician fully described, making it clear that all assessments of disease activity in any individual were undertaken by the same physician throughout the trial (Zurier et al., 1996). The other two studies may have been compromised by inter-rater variability (Leventhal et al., 1993; 1994).

Only one large dose study included dichotomous data for participants who reported AEs: 4 (14) participants in the GLA and 1 (13) patients in the placebo group (Leventhal et al., 1993). The relative risk of AEs was higher among patients using the GLA oil than among patients using the placebo oil (RR 3.71, CI 0.47 to 29.06).

\section{Tripterygium wilfordii Hook F extract - Oral}

Although undertaken by the same research team, data from two studies of orally administered Tripterygium wilfordii Hook F extract (TWHF) could not be pooled because the extracts, interventions and measures differed between the two trials (Tao et al., 1989; 2002).

In the earlier study, a $60 \mathrm{mg}$ daily extract dose of TWHF (solvent chloroform/methanol) was compared with placebo in a crossover trial, the first arm of which lasted for 12 weeks. Clinical outcome measures included joint tenderness ( $0-3$; none to severe), joint swelling of 60 joints only, morning stiffness in hours, grip strength $(\mathrm{mmHg})$, and 15-meter walking time in seconds. Improvements were reported in favor of the extract with statistically significant decreases in joint tenderness (MD $-14.00, \mathrm{CI}-19.02$ to -8.98 , $\mathrm{p}<0.01)$ and swollen joint count (MD -3.10, CI -5.53 to $-0.67, p=0.01)$. Non-significant decreases were reported in morning stiffness (MD -1.40, CI -4.18 to $1.38, \mathrm{p}=0.32$ ) and walking time ( $\mathrm{MD}-10.40$, CI -22.07 to $1.27, \mathrm{p}=0.08)$. An increase in grip strength was also demonstrated (MD 3.20, CI -20.01 to 26.41), although this was not statistically significant $(\mathrm{Z}=0.27, \mathrm{p}=0.79)$.

In the later study, larger extract doses of TWHF (solvent ethanol/ethyl/acetate) were used, $180 \mathrm{mg}$ $(\mathrm{n}=10)$ and $360 \mathrm{mg}(\mathrm{n}=10)$ per day. Clinical outcomes were assessed using the ACR core set of measures at the $20 \%, 50 \%$ and $70 \%$ improvement levels (Tao 2002). Eight high-dose and four low-dose patients satisfied the ACR20 improvement criteria at the end of the intervention period compared to none of the patients in the placebo group. These dichotomous data convert to an odds ratio of 17.31 (CI 0.80 to 373.45 ) and 85.00 (CI 3.61 to 2001.33) of satisfying ACR20 improvement criteria when patients consume the extract in a dose of $180 \mathrm{mg}$ or $360 \mathrm{mg}$ TWHF, respectively, compared with placebo.

Graphic presentation of between group comparisons of each of the disease activity component measures (tender joint count, swollen joint count, pain, physical function, patient global, physician global, erythrocyte sedimentation rate, $\mathrm{C}$-reactive protein) indicated that all outcomes were improved in the high-dose group over both the low-dose and placebo groups, and that improvements were observed on all measures in the low-dose group over the placebo group. These data were not reported in a form that allowed extraction for re-analysis.

In both studies, more AEs were seen among patients receiving TWHF than patients receiving placebo. In the earlier study, AEs resulted in four withdrawals, and a severe reaction (fever and aplastic anaemia) occurred in one patient following an overdose of TWHF. One death occurred also, although not thought to be related to the intervention. In the later study, four patients in the placebo group reported AEs, as did six patients in the high-dose and five patients in the low-dose group. In this study, none of the AEs was reported as severe (not require hospitalization). Commonly reported AEs included diarrhoea, headache, and hair loss.

\section{Phytodolor $\mathbf{N}^{\mathrm{R}}$}

Two studies compared a daily dose of 30 drops of the herbal mixture Phytodolor $\mathrm{N}^{\mathrm{R}}$ to placebo, one over two weeks (Meier, 1987) and the other over 12 months (Eberl et al., 1988). Both studies are unpublished randomized controlled clinical trials conducted by the manufacturer (Steigerwald Pharmaceuticals) as part of product development and testing.

Because length of intervention and some of the measures differed between the trials, data could not be 
pooled for meta-analyses. Available mean data are reported for descriptive comparison. For one study, mean changes from baseline were calculated from frequency tables (Eberl et al., 1988). Standard deviations could not be calculated from the data provided.

Both studies reported cumulative use of NSAIDs (diclofenac) over the course of the trials and reported greater total NSAID use in the Phytodolor $\mathrm{N}^{\mathrm{R}}$ than in the placebo groups. In the longer-term trial, there was evidence that NSAID use in the Phytodolor $\mathrm{N}^{\mathrm{R}}$ group fell below that of the placebo group from months 2 to 11, but reasons for the lower NSAID consumption are not well explained in the study (Eberl et al., 1988).

For several herbal medicines, only one study was available.

\section{SKI306X}

In a single, well-designed, multicentre trial, the Korean herbal mixture SKI 306X was tested against celecoxib in a six-week head-to-head comparison (Song et al., 2007). Pain, measured using a $100 \mathrm{~mm}$ VAS, decreased significantly in both groups over time $(\mathrm{p}<0.01)$, but was not significantly different between groups. These results provide moderate quality evidence that SKI306X is comparable to celecoxib for pain reduction in patients with RA.

After three weeks of intervention, 16 patients receiving SKI306X and 24 patients receiving celecoxib satisfied the ARC20 improvement criteria, whereas another three weeks later equal patient numbers in both groups $(n=29)$ satisfied these criteria. Considering each of these criteria individually (28 tender and swollen joint counts; patients' global assessment; investigators' global assessment; HAQ-DI score; Westergren ESR, CRP), there were no significant differences between the two groups at baseline, week 3 or week 6 , on any measures except erythrocyte sedimentation rate. Mean ESR was slightly, but not significantly, higher in the SKI306X group at baseline, and dropped to significantly less than the mean ESR in the celecoxib group at both, week 3 $(\mathrm{p}<0.04)$ and week $6(\mathrm{p}=0.01)$. These results offer moderate quality evidence that SKI306X and celecoxib have comparable effects on reducing disease activity in patients with RA.

AEs did not differ significantly between the two groups. Gastrointestinal complaints (epigastric pain, abdominal discomfort, nausea, anorexia, dyspepsia) were most common. In the SKI306X group, two patients discontinued the study medication because of depression (serious drug-related event) and because of epigastric pain. The reasons for the three withdrawals in the celecoxib group were pruritus, abdominal discomfort, and skin rash.

\section{Willow bark extract}

A proprietary extract of willow bark (Salix daphnoides) with $240 \mathrm{mg}$ salicin in the daily dosage was compared with placebo in a small sample $(n=26)$ of patients with RA (Biegert et al., 2004). After six weeks of treatment, the extract was not significantly more effective than placebo in producing change from baseline in any clini- cal outcome (pain VAS 0-100; 28 tender and swollen joint counts; patient and physician assessments of efficacy; HAQ-DI score; SF-36 physical and mental component summary scores). This lack of statistical significance may be a Type II error in a small sample, underpowered study.

Three patients (willow bark $\mathrm{n}=2$, group placebo $\mathrm{n}=$ 1) satisfied ACR20 response criteria after six weeks of intervention. Similar numbers $(n=7)$ and severity of AEs were reported for both groups, although it is unclear how many patients these reported.

\section{Uncaria tomentosa extract}

A proprietary extract of Uncaria tomentosa (cat's claw) was compared with placebo in a double-blind randomized controlled trial (Mur et al., 2002). Significant improvements were reported in 68 tender joint count both within and between groups after 24 weeks of treatment $(\mathrm{p}=0.044)$. Also, significant within group improvements were found in the group consuming cats claw on measures of 66 tender joint count ( $\mathrm{p}=$ $0.001)$, Ritchie index $(\mathrm{p}=0.002)$ and duration of morning stiffness $(p=0.002)$. No improvements either between or within groups, were reported for any other clinical or laboratory variables. Twelve patients in each group reported AEs, and one patient from each group withdrew from the study because of the AE.

\section{Powdered Tanacetum parthenium}

Daily use of dried, powdered feverfew (Tanacetum parthenium) was compared with placebo (cabbage) in 41 patients with RA (Patrick et al., 1989). Of the clinical outcomes measured in this study (duration of morning and inactivity stiffness, pain (10 cm VAS), grip strength, Rtichie index). Grip strength was reported to be significantly improved in the feverfew group over time $(p=0.03)$ and in comparison to the placebo group after six weeks of intervention $(p=0.047)$. But recalculation of the between group comparison for this review returned a non-significant $\mathrm{p}$ value of 0.19 . No significant differences were reported either between or within groups on any other clinical measures. One patient in each group reported mild AEs; the patient in the placebo group withdrew from the study because of this.

\section{RA-1}

An Ayurvedic herbal mixture, RA-1, was compared with placebo in patients with RA (Chopra et al., 2000). Data from 182 patients were included in an intentionto-treat analysis although only 165 participants completed the full 16-week trial (per protocol). Change scores on all clinical variables were greater in the RA-1 group than in the placebo group after 16 weeks of intervention, but not statistically significant.

In the per protocol sample, clinical outcomes were further assessed using the ACR core set of measures at the $20 \%$ and $50 \%$ improvement levels (Chopra et al., 2000). Thirty-nine (group RA-1 $\mathrm{n}=80$ ) and 30 (group 
placebo $\mathrm{n}=85$ ) patients satisfied the ACR20 improvement criteria at the end of the intervention period. These dichotomous data convert to an odds ratio of 1.74 (CI 0.93 to $3.26, p=0.08$ ) of patients in the RA-1 group satisfying ACR20 improvement criteria. A significant difference was also noted between the groups for the number of ACR50 responders: 15 (group RA-1) and 5 (group placebo) corresponding to an odds ratio of 3.69 (CI 1.27 to $10.70, p=0.02$ ). These results may be considered to represent silver level evidence that 16 weeks of daily use of RA-1 is superior to placebo for reducing disease activity in RA measured as ACR50 response criteria.

\section{Boswellia serrata extract}

A proprietary gum resin extract of Boswellia serrata (H15) was tested in 78 patients with active RA in two randomized controlled trials in four centres. Results from 37 patients in one centre (Ratingen) were reanalyzed, and demonstrated no significant effectiveness over placebo in either clinical or laboratory outcomes (Sander et al., 1998). Data were not normal distributed, and consequently reported as median and range. Data in this form could not be extracted for analysis in this review. Median subjective pain assessments (VAS 0-10) worsened from 4.6 to 4.7 in the Boswellia group and improved from 3.9 to 3.8 in the placebo group; however, these small changes in pain may be unimportant in light of the baseline differences between groups on this measure. Median subjective global assessment improved in both groups, from 5.0 to 4.9 in the Boswellia group and from 4.7 to 4.2 in the placebo group.

\section{CAPSAICIN - TOPICAL}

Topical capsaicin for control of RA hand pain was compared to placebo in two studies. In both studies, the placebos were vehicle creams prepared and packaged to appear indistinguishable from the active agent, but blinding and placebo validity may have been compromised by a local burning sensation that may occur as an AE with topical capsaicin application. In one study, burning at the site of application was noted by $44 \%$ of patients treated with capsaicin and by one treated with placebo (Deal et al., 1991).

In the larger of the two trials $(\mathrm{n}=31$; Deal et al., 1991), four-times-daily topical use of $0.025 \%$ wv capsaicin cream demonstrated a trend to improve pain. Percentage changes showed a MD of -25.00 (CI -51.76 to $1.76, \mathrm{p}=0.07)$ for pain assessed on a $100 \mathrm{~mm}$ VAS and a MD of -0.47 (CI -1.08 to $0.14, \mathrm{p}=0.13$ ) for pain assessed on a categorical pain scale. Small sample size means that this study was probably underpowered, increasing the likelihood of Type II error. Change from baseline of the physician's global evaluation (-1 to 3, higher score indicating greater improvement) also favored the treatment group, and the difference between groups in this measure was statistically significant after four weeks of intervention $(\mathrm{MD}=1.36$, CI 0.52 to 2.20, $\mathrm{p}=0.001)$. Burning at the site of application of the cream was the only $\mathrm{AE}$ reaction reported in this study.
A further study compared a higher dose $(0.075 \% \mathrm{wv})$ capsaicin cream to placebo (McCarthy and McCarthy, 1992). The sample size was very small; of the seven patients, five completed the four-week trial. Although improvements in pain were measured on a $100 \mathrm{~mm}$ VAS, data from this study were not adequately reported to allow extraction for pooled analysis with the larger study.

\section{Tripterygium wilfordii - Topical}

Sixty-one patients with RA participated in a six-week, randomized, double-blind, placebo-controlled trial of a topically applied tincture of Tripterygium wilfordii (Cibere et al., 2003). The placebo tincture was prepared and packaged to be indistinguishable from the intervention. The tincture was applied up to six times per day to the swollen or tender joints, and results were reported using the core set of ACR response criteria, aggregated into a slightly modified form of the $20 \%$ improvement level. At the end of the intervention period, statistically significant differences were identified between the two groups on most clinical outcomes: 42 tender joint count (MD 1.50, CI 0.58 to 2.42, $\mathrm{p}=0.001$ ), 40 swollen joint count (MD 4.40, CI 2.76 to 6.04, $\mathrm{p}<0.001$ ), grip strength in kiloPascals (MD 39, CI 25.70 to 52.30, p < 0.001), and duration of morning stiffness in hours (MD 0.80, CI 0.54 to $1.06, \mathrm{p}<0.001)$. A significant difference was noted between the groups for the number of ACR20 responders; 18 of 31 patients in the Tripterygium group and 6 of 30 patients in the placebo group. These data represent an odds ratio of 5.54 (CI 1.76 to $17.39, \mathrm{p}=0.003$ ) for the Tripterygium group in satisfying ACR20 improvement criteria. These results may be considered as silver level evidence that six weeks of daily topical Tripterygium application is superior to placebo for reducing RA disease activity.

Summary tables and details of the calculations are presented on the webpage www.uniklinik-freiburg. de/rechtsmedizin/live/forschung/phytomedicine/ originalartikel.html. No serious AEs were reported with any herbal intervention except with oral Tripterygium wilfordii extract.

\section{DISCUSSION}

Several of the studies included in this review were poorly described, and incomplete reporting may have led to those studies being undervalued. In particular, we made strict judgements of methodological quality on the basis of reporting (Higgins and Green, 2008), but not all reviewers agreed that this approach was the most suitable. In 1990, the International Conference on Harmonisation ( $\mathrm{ICH}$ ) of Technical Requirements for Registration of Pharmaceuticals for Human Use was established to bring together regulatory authorities in Europe, Japan and the United States and experts from the pharmaceutical industry to determine scientific and technical aspects of product registration. In these countries, ICH guidelines are implemented in the law, and Human Research Ethics Committees would not approve a clinical trial protocol discordant with the $\mathrm{ICH}$ good clinical practice consolidated guidelines (ICH, 2004). One reviewer argued that for studies conducted in the 
European Union, Japan, Canada, or the USA after 1990, we could assume that randomization, blinding, masking of outcome assessment, and allocation concealment were adequately conducted even if it the study was simply reported as 'randomized and double-blind'. In order to be consistent in our treatment of all studies included in this review, we based our judgements on information reported in the manuscripts, but we acknowledge that systemic regulation of clinical trials is likely to improve the quality of study design. For example, we recognize that properly constituted Human Research Ethics Committees would only approve study protocols with adequate explanation of inclusion and exclusion criteria, reliable and valid outcome measures, and appropriate planned statistical analyses. The increasingly common requirements to register clinical trial protocols and provide evidence of ethics committee approval prior to publishing study reports in reputable medical journals is also helping to increase transparency. To allow full and accurate assessment of future studies, we recommend that authors conform to the Consolidated Standards of Reporting Trials (CONSORT; Begg et al., 1996; Moher, 2001).

Three studies in this review were of confirmatory design, meaning that they were fully powered studies planned to further investigate trends to effectiveness demonstrated in earlier studies (Biegert et al., 2004; Cibere et al., 2003; Song et al., 2007). Several studies, although well designed, were probably underpowered due to small sample size and difficulties with recruitment and lack of evidence of effect may be due to Type II error. Trends to effectiveness may be suggested from underpowered studies if improvements can be calculated and reported as effect sizes (Andersen and Stoové, 1998; Stoové and Andersen, 2003). Even small effect sizes may represent clinically meaningful improvements, particularly if these small effects represent improvements in a condition with a substantial burden of disease (e.g., RA).

The review demonstrates that there is sparse evidence supporting the use of herbal medicines in the treatment of RA. For only five of the HMPs studied, was more than one study available. Due to the heterogenity of the studies, different doses and differences in the active principle of the HMPs which is related to the individual solvent and drug-extract ratio, further clinical trials are needed for a convincing evidence of effectiveness. For all herbal medicines, the optimum dose and duration of treatment needs to be defined. Several studies were of poor quality and were inconsistent with current clinical trial standards in rheumatology. Only five studies used the set of outcome measure recommended by the American College of Rheumatology (ACR) since 1995 (Chopra et al., 2000; Tao et al., 2002; Cibere et al., 2003; Biegert et al., 2004; Song et al., 2007): 20\% improvement in tender and swollen joint counts and $20 \%$ improvement in three of five ACR core set measures including patient and physician global assessments, pain and disability measures, and laboratory evaluation of an acute phase reactant (ESR, CRP: Felson et al., 1993; 1995). In two of these studies, the ACR20 included the HAQ-DI as a measure of disability (Cibere et al., 2003; Song et al., 2007). For future studies, we recommend that researchers use ACR outcome measures to allow comparison of effect sizes between different herbal medicines, and to provide estimates of clinical relevance.
Concerns have been raised about the costs and associated adverse reactions to herbal medicines (Atherton, 1994; Ernst, 1995; 1996; 1998). In general, people with RA have three times the direct medical costs, twice the hospitalization rate and ten times the work disability rates compared to the age- and sex-matched population (Feltsand Yelin, 1989). Although the use of plants as medicines is fundamental to traditional healthcare systems throughout the world, the costs of herbal interventions are rarely covered by modern public health systems. We recommend that future trials of herbal therapies for RA include measures of the costs of care so that the direct costs of these interventions might be compared with the already high costs of other RA treatments.

All RA medicines are associated with AEs and routine prevention measures such as screening for hypertension, osteoporosis, renal insufficiency or cancer should be included in the reassessments (Tugwell, 2004). Although some of the trials include AE data, adequate evidence on safety is not available for any of the herbal medicinal products considered in this review. According to international guidelines (ICH, 2004), results from genotoxicity studies, toxicokinetic, and mechanistic studies are essential for preclinical safety assessment. Carcinogenicity studies are only required when human exposure warrants the need for information from lifetime studies in animals in order to assess the carcinogenic potential. Also recommended are pharmacological trials of six and nine months for chronic toxicity assessment in rodents and non-rodents respectively. None of the herbal medicinal products considered in this review have been subject to this rigorous non-clinical testing, and therefore, cannot be recommended during pregnancy or lactation.

Herbal preparations may also be contaminated with other herbs, pesticides, herbicides, heavy metals, or drugs. Contamination is unlikely if the holder of manufacturing authorization complies with the principles and guidelines of good manufacturing practice (GMP) for medicinal products, and uses starting materials which have been manufactured in accordance with the GMP guidelines (EFPIA, 1996).

The safety profile for preparations from Tripterygium wilfordii Hook $\mathrm{F}$ is particularly concerning. This herb is no longer included in the English edition of the Chinese Pharmacopeia, probably due to the toxicity of the coactive triptolides. AEs include dysmenorhea, decrease of male fertility, renal insufficiency, haematotoxicity, embryotoxicity and immune suppression demonstrated by increased rate of infections (Canter et al., 2006). The rodent $\mathrm{LD}_{50}$ for the ethyl alcohol and chloroform extracts were $608-858 \mathrm{mg} / \mathrm{kg}$ and $160 \mathrm{mg} / \mathrm{kg}$, respectively, depending on the source of the plant and the time of harvest. Subacute toxicity showed pathological changes mainly in the lymphatic and reproductive systems. The risk-benefit trade-off of Tripterygium wilfordii Hook F may be judged as unfavorable (Canter et al., 2006).

The US National Library of Medicine and the National Institutes of Health summarized safety data for EPO (www.nlm.nih.gov/medlineplus/druginfo/ natural/patient-primrose.html). Allergy or hypersensitivity seems to be rare, but contact dermatitis (skin rash) is possible. Several reports described seizures in individuals taking EPO, particularly in people with a history 
of seizure disorders, and among individuals taking EPO in combination with anaesthetics or other centrally acting drugs such as chlorpromazine, thioridazine, trifluoperazine, or fluphenazine. Doses of antiseizure medications may require an increase of the dosage. People who plan to undergo surgery requiring general anaesthesia are advised to stop taking EPO two weeks prior. Other adverse events include occasional headache, abdominal pain, nausea, and loose stools. In animal studies, GLA decreased blood pressure. Early results in human studies do not show consistent changes in blood pressure but people on blood pressure medications should closely monitor their blood pressure. Since borage and blackcurrant seed oils also contain GLA, the adverse event profiles may be similar.

Optimum duration of treatment with GLA is uncertain. Benefits appeared to be increased if dosages were in excess of $1.4 \mathrm{~g}$ daily and were administered for at least six months' duration although it seems that maximum benefit may not be achieved within this time period. One problem seen in studies where larger doses of GLA were given was related to the large quantity, and large size, of capsules required to achieve higher dosages. Future studies might address this problem by evaluating the effects of lower dosages over a longer period of time.

Feverfew is a traditional medicine for the prevention of migraine, although its effectiveness has not yet been proven beyond any doubt (Pittler and Ernst, 2004). Preclinical safety data are not available (ESCOP, 2003). Rare cases of allergy, diarrhoea, flatulence, nausea or vomiting have been noted. Cases of abdominal pain and indigestion in patients who have taken feverfew for long periods have been reported (ESCOP, 2003). From time to time a pause in treatment is advisable with gradual reduction of dosage during the preceding month. It remains to be established if feverfew is an alternative treatment option for RA.

Willow bark extract contains a gastroprotective principle (Glinko, 1998; Gürbüz et al., 2003) which may be of advantage in light of the gastrointestinal adverse events possible among people concomitantly using NSAIDs (Ofman et al., 2002). According to the ESCOP monograph, treatment with willow bark extract is not restricted (ESCOP, 2003). Severe specific effects have not yet been observed in the doses employed except in rare cases allergic skin reactions. In people with known sensitivity to salicylates, the use of willow bark preparations should be avoided. Although willow bark has only little impact on blood clotting (Krivoy et al., 2001), interaction studies investigating doses systematically are needed to rule out any skepticism. Dental extractions or operations do not appear to be contraindicated, but robust preclinical safety data are needed.

The adverse effect profile for Phytodolor $\mathrm{N}^{\mathrm{R}}$ appears to be better than for NSAIDs. Gastrointestinal complaints were most frequently reported $(2.6 \%)$, and occasionally, allergic skin reactions have occurred. Some adverse effects are partly due to the alcohol content of Phytodolor $\mathrm{N}^{\mathrm{R}}$ (45.6\% vol, $0.7 \mathrm{~g}$ per 40 drops) which may pose a health risk to children, and to adults with liver disease, alcoholism, epilepsy, or brain-damage. Caution is advised during pregnancy or lactation and for drivers and individuals who operate machines, even though no impairment of consciousness or reactivity is expected to occur with $0.7 \mathrm{~g}$ of alcohol per dose. Studies on mutagenicity, teratogenicity and toxicity in the parent animals and their progeny gave no evidence for any toxic effects arising from the intake of the combination during pregnancy and the lactation period (Gundermann, 2001).

Although SKI306X appeared not to be associated with a higher incidence of adverse events than celecoxib, neither preclinical safety data are available nor interaction studies or long-term studies that prove the safety this HMP. This is a major concern and needs to be ruled out before herbal mixtures such as SKI306X are applied to humans. The active principle of every HMP corresponds to the sum of effects of compounds that may synergistically or antagonistically interact. If three herbal extracts are combined, the superiority of the combination over the individual herbal extracts has to be proven: in vitro, in animal experiments and in human pharmacological studies.

Cat's claw preparations inhibit cytochrome P450 3A4 activities (Budzinski et al., 2000). Such activities are important for drug metabolism by the liver and can prolong the biological activity of drugs. No unwanted physiological changes, organ changes, or toxic effects have been observed when using an aqueous extract in rats (Sheng et al., 2000): the $\mathrm{LD}_{50}$ was reported to be greater than $8 \mathrm{~g} / \mathrm{kg}$. An increase of white blood cells, however, was seen in humans and considered clinically significant because data suggest that cat's claw can stimulate the immune system (Lemaire et al., 1999). Other in vitro experiments using Chinese hamster ovary cells and bacteria failed to demonstrate any toxicity (Rizzi et al., 1993; Santa Maria et al., 1997). The available animal toxicological studies do not indicate severe toxicity from oral intake of cat's claw preparations but suggest a low potential for acute and subacute oral toxicity. This evidence does not suggest genotoxic potential or mutagenic activity.

No data on safety are available for Ayurvedic medicines. The RA-1 product was not standardized (Chopra et al., 2000); therefore, the study cannot be accurately replicated to confirm results because co-active ingredients may differ between product batches. Also, there is no way to determine whether the product has been contaminated with pesticides, herbicides or heavy metals. Contamination is not an issue if manufacturers comply with the principles and guidelines of good manufacturing practice (EFPIA, 1996); a requirement in almost all industrialized countries, but not in India where the study was undertaken.

Capsaicin may cause skin irritation. It may be absorbed through skin (particularly abraded skin) and activate dermal pain fibers and cause a burning sensation. There is some concern that capsaicin may be potentially neurotoxic, although clinical studies with topical capsaicin have not shown this to occur. It is thought to be capable of elevating the heat-pain threshold in treated skin areas. Capsaicin may cause irritation of the eyes with redness, pain, lacrimation, tearing, and blepharospasm. After inhalation it may cause respiratory tract and mucous membrane irritation with coughing, wheezing, burning sensation in nose and throat, and laryngitis (ESCOP, 2003). Capsaicin given to newborn rats results in an irreversible loss of specific sensory functions by selective degeneration of approximately $50 \%$ of sensory ganglion cells (Lawson and Nickels, 1980; Fitzgerald, 1983). The administration of capsaicin 
in adult rats induces progressive rapid deterioration of structural integrity of some B-type primary sensory neurons, leading to the degeneration of these cells (Jansco and Kiraly, 1981). Long-term studies on neurotoxicity are required to rule out any possible harm in humans.

The current available evidence for herbal treatment of RA is generally sparse and reliant on small sample sizes and is therefore insufficient for reliable assessment of efficacy to be made. The studies of GLA are of sufficient interest to warrant further investigation. Variability between studies indicates a need to establish efficacy, optimum dosage and duration of treatment. The single studies are inconclusive. Good tolerance of most of the herbal remedies was demonstrated although caution is warranted in interpreting safety due to small sample size in some of the studies. The trend for self-medication with over-the-counter herbal remedies, especially in the treatment of chronic disease, makes further research in the field desirable. Non-clinical studies are required to determine the toxicity profiles of almost all herbal medicines in common use for the treatment of RA.

\section{REFERENCES}

ACR - American College of Rheumatology Subcommittee on Rheumatoid Arthritis Guidelines. 2002. Guidelines for the management of rheumatoid arthritis: 2002 update. Arthritis Rheum 46: 328-346.

Aguilar JL, Rojas P, Marcelo A, Plaza A, Bauer R, Reininger E, Klaas CA, Merfort I. 2002. Anti-inflammatory activity of two different extracts of Uncaria tormentosa (Rubiaceae). J Ethnopharm 81: 271-276.

Allen-Hall L, Cano P, Arnason JT, Rojas R, Lock O, Lafrenie RM. 2007. Treatment of THP-1 cells with Uncaria tomentosa extracts differentially regulates the expression if IL-1beta and TNF-alpha. J Ethnopharm 109: 312-317.

Altmann A, Poeckel D, Fischer L, Schubert-Zsilavecz M, Steinhilber D, Werz, O. 2004. Coupling of boswellic acid-induced $\mathrm{Ca} 2+$ mobilisation and MAPK activation to lipid metabolism and peroxide formation in human leucocytes. B. J Pharmacol 141: 223-232.

Ammon HP, Mack T, Singh GB, Safayhi H. 1991. Inhibition of leukotriene B4 formation in rat peritoneal neutrophils by an ethanolic extract of the gum resin exudate of Boswellia errata. Planta Med 57: 203-207.

Ammon HP, Safayhi H, Mack T, Sabieraj J. 1993. Mechanism of anti-inflammatory actions of curcumine and boswellic acids. J Ethnopharmacol 38: 113-119.

Andersen MB, Stoové MA. 1998. The sanctity of $p>.05$ obfuscates good stuff: A comment on Kerr and Goss. J Appl Sport Psychol 10: 168-173.

Arnett FC, Edworthy SM, Bloch DA, McShane DJ, Fries JF, Cooper NS, Healey LA, Kaplan SR, Liang HH, Luthra HS, Medsger Jr TA, Mitchell DM, Neustadt DH, Pinals RS, Schaller JG, Sharp JT, Wilder RL, Hunder GG. 1988. The American Rheumatism Association 1987 revised criteria for the classification of rheumatoid arthritis. Arthritis Rheum 31: 315-324.

Astin JA. 1998. Why patients use alternative medicine: Results of a national study. JAMA 279: 1548-1553.

Atherton DJ. 1994. Towards the safer use of traditional remedies. BMJ 308: 673-674.

Begg C, Cho M, Eastwood S, Horeton R, Moher D, Olkin I, Pitkin R, Rennie D, Schulz KF, Simel D, Stroup DF. 1996. Improving the Quality of Reporting of Randomized Controlled Trials. The CONSORT Statement. JAMA 276: 637-639.

Belch JJF, Ansell D, Madhok R, O'Dowd A, Sturrock D. 1988. Effects of altering dietary essential fatty acids on requirements for non-steroidal anti-inflammatory drugs in patients with rheumatoid arthritis: a double blind placebo controlled study. Ann Rheum Dis 47: 96-104.

Biegert C, Wagner I, Ludtke R, Kotter I, Lohmuller C, Gunaydin I, Taxis K, Heide L. Efficacy and safety of willow bark extract in the treatment of osteoarthritis and rheumtoid arthritis: Results of 2 randomized double-blind controlled trials. 2004. J Rheumatol 31: 2121-2130.

Boisset M, Fitzcharles M. 1994. Alternative medicine use by rheumatology patients in a universal health care setting. $J$ Rheumatol 21: 148-152.

Brzeski M, Madhol R, Capell HA. 1991. Evening primrose oil in patients with rheumatoid arthritis and side-effects of nonsteroidal anti-inflammatory drugs. $\mathrm{Br} J$ Rheumatol 30: 370-372.
Buchbinder R, Gingold M, Hall S, Cohen M. 2002. Nonprescription complementary treatments used by rheumatoid arthritis patients attending a community-based rheumatology practice. Int Med J 23: 208-214.

Buck SH, Burks TF. 1986. THe neuropharmacology of capsaicin: Review of some recent observations. Pharm Rev 38: 179-226.

Budzinski JW, Foster BC, Vandenhoek S, Arnason JT. 2000. An in vitro evaluation of human cytochrome P450 3A4 inhibition by selected commercial herbal extracts and tinctures. Phytomedicine 7: 273-282.

Canter PH, Lee HS, Ernst E. 2006. A systematic review of randomised clinical trials of Tripterygium wilfordii for rheumatoid arthritis. Phytomedicine 13: 371-377.

Capasso F. 1986. The effect of an aqueous extract of Tanacetum parthenium L. on arachidonic acid metabolism by rat peritoneal leucocytes. J Pharm Pharmacol 38: 71-72.

Chang DM, Chang WY, Kuo SY, Chang ML. 1997. The effects of traditional antirheumatic herbal medicines on immune response cells. J Rheumatol 24: 436-441.

Chevrier MR, Ryan AE, Lee DY, Zhongze M, Wu-Yan Z, Via CS. 2005. Boswellia carterii extract inhibits TH1 cytokines and promotes TH2 cytokines in vitro. Clin Diagn Lab Immunol 12: $75-80$.

Chilton-Lopez, Surette ME, Swan DD, Fonteh AN, Johnson MM, Chilton FH. 1996. Metabolism of gammalinolenic acid in human neutrophils. J Immunol 156: 2941-2947.

Choi JH, Choi JH, Kim DY, Yoon JH, Youn HY, Yi JB, Rhee HI, Ryu KH, Jung K, Han CK, Kwak WJ, Cho YB. 2002. Effects of SKI 306X, a new herbal agent, on proteoglycan degradation in cartilage explant culture and collagenase-induced rabbit osteoarthritis model. Osteoarthritis Cartilage 10: 471-478.

Chopra A, Lavin P, Patwardhan B, Chitre D. 2000. Randomized double-blind trial of an Ayurvedic plant derived formulation for treatment of rheumatoid arthritis. J Rheumatol 27: $1365-1372$.

Chou CT, Chang SC. 1998. The inhibitory effect of common traditional anti-rheumatic herb formulas on prostaglandin E and interleukin 2 in vitro: a comparative study with Tripterygium wilfordii. J Ethnopharmacol 62: 167-171.

Chrubasik S, Eisenberg E. 1998. Treatment of rheumatic pain with herbal medicine in Europe. Pain Digest 8: 231236.

Chrubasik S, Wink M. 1998. Traditional herbal therapy for the treatment of rheumatic pain: Preparations from Devil's Claw and Stinging Nettle. Pain Digest 8: 94-101.

Chrubasik JE, Roufogalis BD, Chrubasik S. 2007. Evidence of effectiveness of herbal anti-inflammatory drugs in the treatment of painful osteoarthritis including chronic low back pain. Phytother Res 21: 675-683.

Cibere J, Deng Z, Lin Y, He Y, Wang Z, Thorne A, Lehman AJ, Tsang IK, Esdale JM. 2003. A randomized double blind placebo controlled trial of topical Tripterygium wilfordii in rheumatoid arthritis: Reanalyais using logistic regression. J Rheumatol 30: 465-467.

Collier HO, Butt NM, McDonald-Gibson WJ, Saeed SA. 1980. Extract of feverfew inhibits prostaglandin biosynthesis. Lancet 2: 922-923. 
Cronan TA, Kaplan RM, Posner L, Blumberg E, Franklin K. 1989. Prevalence of the use of unconventional remedies for arthritis in a metropolitan community. Arthritis Rheum 32: 1604-1607.

Deal CL, Schnitzer TJ, Lipstein E, Seibold JR, Stevens RM, Levy MD, Albert D, Renold F. 1991. Treatment of arthritis with topical capsaicin: A double-blind trial. Clin Ther 13: 383-395.

Dedov VN, Roufogalis BD. 2000. Mitochondrial calcium accumulation following activation of vanilloid (VR1) receptors by capsaicin in dorsal root ganglion neurons. Neurosci 95: 183-188.

DeLuca P, Rossetti RG, Alavian C, Karim P, Zurier RB. 1999. Effects of gammalinolenic acid on interleukin-1 beta and tumor necrosis factor-alpha secretion by stimulated human peripheral blood monocytes: studies in vitro and in vivo. $J$ Invest Med 47: 246-250.

Dooper MM, van Riel B, Graus YM, M'Rabet L. 2003. Dihomogamma-linolenic acid inhibits tumour necrosis factor-alpha production by human leucocytes independently of cyclooxygenase activity. Immunology 110: 348-357.

Eberl R, Dunky A, Leeb B, Wohanka A. 1988. Savings of nonsteroidal antirheumatics by Phytodolor: Placebo-controlled, double blind study over a period of one year per patient. Unpublished report for steigerwald pharmaceuticals. Author: Darmstadt, Germany.

EFPIA - European Federation of Pharmaceutical Industries and Associations. Available at www.gmp-compliance.org/eca guidelinelist_part3.html. Accessed: 10 June 2008.

Ernst E, Willoughby M, Weihmayr TH. 1995. Nine possible reasons for choosing complemetary medicine. Perfusion 8 : 356-358.

Ernst E. 1995. Bitter pills of nature: Safety issues in complementary medicine. Pain 60: 237-238.

Ernst E. 1996. Plants as medicine: possible benefits and potential risks. Br J Ther Rehab 3: 82, 99-100.

Ernst E. 1998. Over-the-counter complementary remedies used for arthritis. Pharmaceut J 260: 830-831.

ESCOP - European Scientific Cooperative on Phytotherapy. 2003. ESCOP Monographs. Thieme-Verlag Stuttgart: New York.

Felson DT, Anderson JJ, Boers M, Bombardier C, Chernoff M, Fried B, Furst D, Goldsmith C, Kieszak S, Lightfoot R, Paulus $M$, Tugwell P, Weinblatt M, Widmark R, Williams MJ, Wolfe F. 1993. The American College of Rheumatology preliminary core set of disease activity measures for rhematoid arthritis clinical trials. Arthritis Rheum 36: 729-740.

Felson DT, Andersen JJ, Boers M, Bombardier C, Furst D, Goldsmith C, Katz LM, Lightfoot Jr R, Paulus M, Strand V Tugwell P, Weinblatt M, Williams MJ, Wolfe F, Kieszak, S. 1995. American College of Rheumatology preliminary definition of improvement in rheumatoid arthritis. Arthritis Rheum 38: 727-735.

Felts W, Yelin E. 1989. The economic impact of the rheumatic diseases in the United States. J Rheumatol 16: 867-884.

Fiebich BL, Chrubasik S. 2004. Effects of an ethanolic salix extract on the release of selected inflammatory mediators in vitro. Phytomedicine 11: 135-138.

Fitzgerald M. 1983. Capsaicin and sensory neuron. A review. Pain 15: 109-130.

Flynn DL, Rafferty MF, Boctor AM. 1986. Inhibition of human neutrophil 5-lipoxygenase activity by gingerdione, shogaol, capsaicin and related pungent compounds. Prostoglandins Leukot Med 24: 195-198.

Fukuda K, Hibiya Y, Mutoh M, Ohno Y, Yamashita K, Akao S, Fujiwara H. 2000. Inhibition by parthenolide of phorbol ester-induced transcriptional activation of inducible nitric oxide synthase gene in a human monocyte cell line THP-1. Biochem Pharmacol 60: 595-600.

Furse RK, Rossetti RG, Zurier RB. 2001. Gammalinolenic acid, an unsaturated fatty acid with anti-inflammatory properties, blocks amplification of IL-1 beta production by human monocytes. J Immunol 67: 490-496.

Furse RK, Rossetti RG, Seiler CM, Zurier RB. 2002. Oral administration of gammalinolenic acid, an unsaturated fatty acid with anti-inflammatory properties, modulates interleukin1 beta production by human monocytes. J Clin Immunol 22: 83-91.

Gayathri B, Manjula N, Vinaykumar KS, Lakshmi BS, Balakrishnan A. 2007. Pure compound from Boswellia serrata extract exhibits anti-inflammatory property in human PBMCs and mouse macrophages through inhibition of TNF $\alpha, \mathrm{IL}-1 \beta$, NO and MAP kinases. Int Immunopharmacol 7: 473-482.

Glaser T, Winter S, Groscurth P, Safayhi H, Sailer ER, Ammon HP, Schabet M, Weller M. 1999. Boswellic acids and malignant glioma: Induction of apoptosis but no modulation of drug sensitivity. $\mathrm{Br} J$ Cancer 80: 756-765.

Glinko A. 1998. Pharmacological properties of a standardized extract from Willow bark (Cortex salicis). Thesis: Pomeranian Academy of Medicine, Poland.

Goncalves C, Dinis T, Batista MT. 2005. Antioxidant properties of pro-anthocyanidins of Uncaria tomentosa bark decoction: A mechanism for anti-inflammatory activity. Phytochemistry 66: 89-98.

Gürbüz I, Ustün O, Yesilada E, Sezik E, Kutsal O. 2003. Antiulcerogenic activity of some plants used as folk remedy in Turkey. J Ethnopharmacol 88: 93-97.

Gundermann KJ. 2001. Clinical expert report. Steigerwald: Darmstadt, Germany.

Guo W, Ma L, Tao X. 2001. [In vitro inhibitive effects of Tripterygium wilforii on NO production, iNOS activity, and iNOSmRNA expression in chondrocyrtes of patients with rheumatoid arthritis] [Article in Chinese]. Zhonghua Yi Xue Za Zhi 81: 1035-1037.

Hartwich A, Germann I, Kelber O, Muller J, Weiser D, Heinle H. 2006. Das pflanzliche Rheumapräparat STW 1 hat antioxidative Effekte. Zschr Rheumatol 65(Supp 1): 528.

Higgins JPT, Green S. 2008. The Cochrane Handbook for Systematic Review of Interventions. Wiley-Blackwell: Chichester, UK.

Ho LJ, Chang DM, Chang ML, Kuo SY, Lai JH. 1999. Mechanism of immunosuppression of the antirheumatic herb TWHf in human T cells. J Rheumatol 26: 14-24.

Hwang D, Fischer $\mathrm{NH}$, Jang BC, Tak H, Kim JK, Lee W, 1996. Inhibition of the expression of inducible cyclooxygenase and proinflammatory cytokines by sesquiterpene lactones in macrophages correlates with the inhibition of MAP kinases. Biochem Biophys Res Commun 226: 810-818.

$\mathrm{ICH}$ 2004. International Conference on Harmonisation of Technical Requirements for Registration of Pharmaceuticals for Human Use: Synopsis of ICH guidelines and topics. Author: Geneva, Switzerland.

Iverson L, Fogh K, Kragbelle K. 1992. Effect of dihomogammalinolenic acid and its 15-lipoxygenase metabolite on eicosanoid metabolism by human mononuclear leukocytes in vitro: Selective inhibition of the 5-lipoxygenase pathway. Arch Dermatol Res 284: 222-226.

Jäntti J, Seppala E, Vapaatalo H, Isomaki H. 1989a. Evening primrose oil and olive oil in treatment of rheumatoid arthritis. Clin Rheumatol 8: 238-234.

Jäntti J, Nikkari T, Solakivi T, Vapaatalo H, Isomake H. 1989b. Evening primrose oil in rheumatoid arthritis: changes in serum lipids and fatty acids. Ann Rheum Dis 48: 124-127.

Jancso G, Kiraly E. 1981. Capsaicin-induced degeneration of neuron in brain. Brain Res 210: 83-89.

Jiang WG, Puntis MC, Horrobin DF, Scott C, Hallett MB. 1996. Inhibition of neutrophil respiratory burst and cytokine priming by gamma-linolenic acid. Br J Surg 83: 659-664.

Jürgensen $S$, Dalbo $S$, Angers $P$, Santos AR, Ribeiro-do-Valle RM. 2005. Involvement of 5-HT2 receptors in the antinociceptive effect of Uncaria tomentosa. Pharmacol Biochem Behav 81: 466-477.

Kahkonen MP, Hopia Al, Vuorela HJ, Rauha JP, Pihlaja K, Kujala TS, Heinonen M. 1999. Antioxidant activity of plant extracts containing phenolic compounds. J Agric Food Chem 47: 3954-3962.

Kang BY, Chung SW, Kim TS. 2001. Inhibition of interleukin-12 production in lipopolysaccharide-activated mouse macrophages by parthenolide, a predominant sesquiterpene lactone in Tanacetum parthenium: involvement of nuclear factor-kappaB. Immunol Lett 77: 159-163.

Khajuria A, Gupta A, Suden P, Singh S, Malik F, Singh J, Gupta BD, Suri KA, Srinivas VK, Ella K, Qazi GN. 2008. Immunomodulatory activity of biopolymeric fraction BOS 2000 from Boswellia serrata. Phytother Res 22: 340-348.

Khayyal MT, El-Ghazaly MA, Abdallah DM, Okpanyi SN, Kelber O, Weiser D. 2005. Mechanisms involved in the antiinflammatory effect of a standardized willow bark extract. Arzneimittel-Forschung/Drug Res 55: 677-687. 
Kim YH, Lee SH, Lee JY, Choi SW, Park JW, Kwon TK. 2004. Triptolide inhibits murine-inducible nitric oxide synthase expression by down-regulating lipopolysaccharide-induced activity of nuclear factor-kappa B and C-Jun NH2-terminal kinase. Eur J Pharmacol 494: 1-9.

Kim JH, Ryu KH, Jung KW, Han CK, Kwak WJ, Cho YB. 2005a. Effects of SKI306X on arachidonate metabolism and other inflammatory mediators. Bio Pharm Bulletin 28: $1615-1620$.

Kim JH, Ryu KH, Jung KW, Han CK, Kwak WJ, Cho YB. 2005b. SKI306X suppresses cartilage destruction and inhibits the production of matrix metalloproteinase in rabbit joint cartilage explant culture. J Pharmacol Sci 98: 298-306.

Krivoy N, Pavlotzky E, Chrubasik S, Eisenberg E, Brooks G. 2001. Effect of Salicis Cortex extract on human platelet aggregation. Planta Med 67: 209-213.

Kuppsamy UR, Khoo HE, Das NP. 1990. Structure-activity studies of flavonoids as inhibitors of hyaluronidase. Biochem Pharmacol 140: 397-401.

Kwok BH, Koh B, Ndubuisi MI, Elofsson M, Crews CM. 2001. The anti-inflammatory natural product parthenolide from the medicinal herb Feverfew directly binds to and inhibits IkappaB kinase. Chem Biol 8: 759-766.

Lawson SN, Nickels SM. 1980. The use of morphometric techniques to analyze the effect of neonatal capsaicin treatment on rat dorsal root ganglia and dorsal root. J Physiol 302: 12.

Lee DM, Weinblatt ME. 2001. Rheumatoid arthritis. Lancet 358: 903-911.

Lemaire I, Assinewe V, Cano P, Awang DV, Arnason JT. 1999. Stimulation of interleukin- 1 and 6 production in alveolar macrophages by the neotropical liana, Uncaria tomentosa (una de gato). J Ethnopharmacol 64: 109-115.

Leventhal LJ, Boyce EG, Zurier RB. 1993. Treatment of rheumatoid arthritis with gammalinolenic acid. Ann Int Med 119: 867-873.

Leventhal LJ, Boyce EG, Zurier RB. 1994. Treatment of rheumatoid arthritis with blackcurrant seed oil. Br J Rheumatol 33: 847-852.

Li RW, David Lin G, Myers SP, Leach DN. 2003. Antiinflammatory activity of Chinese medicinal vine plants. $J$ Ethnopharmacol 85: 61-67.

Lin N, Liu C, Xiao C, Jia H, Imada K, Wu H, Ito A. 2007. Triptolide, a diterpenoid triepoxide, suppresses inflammation and cartilage destruction in collagen-induced arthritis mice. Biochem Pharmacol 73: 136-146.

Li-Weber M, Giaisi M, Treiber MK, Krammer PH. 2002. The anti-inflammatory sesquiterpene lactone parthenolide suppresses IL-4 gene expression in peripheral blood T. Eur $J$ Immunol 32: 3587-3597.

Lin N, Sato T, Ito A. 2001. Triptolide, a novel diterpenoid triepoxide from Tripterygium wilfordii Hook. f., suppresses the production 2001. and gene expression of pro-matrix metalloproteinases 1 and 3 and augments those of tissue inhibitors of metalloproteinases 1 and 2 in human synovial fibroblasts. Arthritis Rheum 44: 2193-2200.

Little CV, Parsons T. 2001. Herbal therapy for treating rheumatoid arthritis. Cochrane Database of Systematic Reviews 2000, Issue 4. Art. No: CD002948. DOI.10.1002/14651858. CD002948.

Liu Q, Chen T, Chen G, Shu X, Sun A, Ma P, Lu L, Cao X. 2007. Triptolide impairs dendritic cell migration by inhibiting CCR7 and COX-2 expression through PI3-K/Akt and NFkappaB pathways. Molec Immunol 44: 2686-2696.

Lorig K, Holman H. 1989. Long-term outcomes of an arthritis self-management study: Effects of reinforcement efforts. Soc Sci Med 29: 221-224.

MacPherson H, Blackwell R. 1994. Rheumatoid arthritis and Chinese medicine. Eur J Oriental Med 1: 17-29.

Maekawa K, Yoshikawa N, Du J, Nishida S, Kitasato H, Okamoto K, Tanaka H, Mizushima Y, Kawai S. 1999. The molecular mechanism of inhibition of interleukin-1beta-induced cyclooxygenase-2 expression in human synovial cells by Tripterygium wilfordii Hook F extract. Inflamm Res 48: 575-581.

McCarthy GM, McCarthy DJ. 1992. Effect of topical capsaicin in the therapy of painful osteoarthritis of the hands. $J$ Rheumatol 19: 604-607.

Meier G. 1987. Phytodolor N versus placebo in rheumatoid arthritis: Pilot study of the rheumatism clinic. Unpublished report for steigerwald pharmaceuticals. Darmstadt, Germany.
Meyer B, Schneider W, Elstner EF. 1995. Antioxidative properties of alcoholic extracts from Fraxinus excelsior, Populus tremula and Solidago virgaurea. Arzneimittel-Forschung/ Drug Res 45: 174-176.

Miller MJ, Ahmed S, Bobrowski P, Haqqi TM. 2006. The chrondoprotective actions of a natural product are associated with the activation of IGF- 1 production by human chondrocytes despite the presence of IL-1beta. BMC Compl Alternat Med 7: 6-13.

Mills SY, Jacoby RK, Chacksfield M, Willoughby M. 1996. Effect of a proprietary herbal medicine on the relief of chronic arthritic pain: A double-blind study. $B r J$ Rheumatol 35: 874-878.

Mittra S, Datta A, Singh SK, Singh A. 2000. 5-Hydroxytryptamineinhibiting property of feverfew: Role of parthenolide content. Acta Pharmacol Sin 21: 1106-1114.

Moher D, Schulz KF, Altman DG. 2001. The CONSORT statement: Revised recommendations for improving the quality of reports of parallel-group randomized trials. Ann Int Med 134: 657-662.

Mur E, Hartig F, Eibl G, Schirmer M. 2002. Randomised double blind trial of an extract from the pentacyclid alkaloid-chemotype of Uncaria tomentosa for the treatment of rheumatoid arthritis. J Rheumatol 29: 678-681.

Nolano M, Simone DA, Wendelschafer-Crabb G, Johnson T, Hazen E, Kennedy WR. 1999. Topical capsaicin in humans: Parallel loss of epidermal nerve fibers and pain sensation. Pain 81: 135-145.

Ofman JJ, MacLean CH, Straus WL, Morton SC, Berger ML, Roth EA, Shekelle P. 2002. A meta-analysis of severe upper gastrointestinal complications of nonsteroidal antiinflammatory drugs. J Rheumatol 29: 804-812.

O'Gradaigh D, Ireland D, Bord S, Compston JE. 2004. Joint erosion in rheumatoid arthritis: Interactions between tumor necrosis factor alpha, interleukin 1, and receptor activator of nulcear factor kappaB ligand (RANKL) regulate osteoclasts. Ann Rheum Dis 63: 354-359.

Pattrick M, Heptinstall S, Doherty M. 1989. Feverfew in rheumatoid arthritis: a double blind, placebo controlled study. Ann Rheum Dis 48: 547-549.

Piela-Smith TH, Liu X. 2001. Feverfew extracts and the sesquiterpene lactone parthenolide inhibit intercellular adhesion molecule-1 expression in human synovial fibroblasts. Cell Immunol 209: 89-96.

Pilarski R, Zielinski H, Ciesiolka D, Gulewicz K. 2006. Antioxidant activity of ethanolic and aqueous extracts of Uncaria tomentosa (Willd.) DC. J Ethnopharmacol 104: 18-23.

Pittler MH, Ernst E. 2004. Feverfew for preventing migraine. Cochrane Dataase of Systematic Reviews 1: CD002286.

Poeckel D, Tausch L, Kather N, Jauch J, Werz O. 2006. Boswellic acids stimulate arachidonic acid release and 12-lipoxygenase activity in human platelets independent of $\mathrm{Ca} 2+$ and differentially interact with platelet-type 12lipoxygenase. Mol Pharmacology 70: 1071-1078.

Pugh WJ, Sambo K. 1988. Prostaglandin synthetase inhibitors in feverfew. J Pharm Pharmacol 40: 743-745.

Purasiri P, Mckechnie A, Heys SD, Eremin O. 1997. Modulation in vitro of human natural cytotoxicity, lymphocyte proliferative response to mitogens and cytokine production by essential fatty acids. Immunology 92: 166-172.

Rizzi R, Re F, Bianchi A, De Feo V, de Simone F, Bianchi L, Stivala LA. 1993. Mutagenic and antimutagenic activities of Uncaria tormentasa and its extracts. J Ethnopharmacol 38: 63-77.

Rohnert U, Schneider W, Elster EF. 1998a. Superoxid-dependent and -independent nitrite formation from hydroxylamine: Inhibition by plant extracts. Zeitschr Naturforsch 53: 241-249.

Rohnert U, Koske D, Schneider W, Elstner E. 1998b. Inhibition by Salix extracts and Phytodolor of copper-catalyzed oxidative destructions. Zeitschr Naturforsch 53: 233-240.

Roy S, Khanna S, Shah H, Rink C, Phillips C, Preuss H, Subbaraju GV, Trimurtulu G, Krishnaraju AV, Bagchi M, Bagchi D, Sen CK. 2005. Human genome screen to identify the genetic basis of the anti-inflammatory effects of Boswellia in microvascular endothelial cells. DNA Cell Biol 24: 244-255.

Roy S, Khanna S, Krishnaraju AV, Subbaraju GV, Yasmin T, Bagchi D, Sen CK. 2006. Regulation of vascular responses to inflammation: inducible matrix metalloproteinase-3 expression in human microvascular endothelial cells is 
sensitive to antiinflammatory Boswellia. Antioxidants Redox Signaling 8: 653-660.

Saadane A, Masters S, DiDonato J, Li J, Berger M. 2007. Parthenolide inhibits IkappaB kinase, NF-kappaB activation, and inflammatory response in cystic fibrosis cells and mice. Am J Respir Cell Mol Biol 36: 728-736.

Safayhi H, Rall B, Sailer ER, Ammon HP. 1997. Inhibition by boswellic acids of human leukocyte elastase. J Pharmacol Exp Ther 281: 460-463.

Sander O, Herborn G, Rau R. 1998. Is H15 (Extract of Boswellia serrata, 'incense') an efficient supplementation to established drug therapy in RA? - Results of a double blinded pilot trial [lst H15 (Harzextrakt von Boswellia serrata, ${ }^{1}$ Weihraucha) eine sinnvolle Ergänzung zur etablierten medikamentösen Therapie der chronischen Polyarthritis? Ergebnisse einer doppelblinden Pilotstudie]. Zschr Rheumatol 57: 11-16.

Sandoval M, Charbonnet RM, Okuhama NN, Roberts J, Krenova Z, Trentacosti AM, Miller MJ. 2000. Cat's claw inhibits TNF $\alpha$ production and scavenges free radicals: Role in cytoprotection. Free Rad Biol Med 29: 71-78.

Sandoval M, Okuhama NN, Zhang XJ, Condezo LA, Lao J, Angeles FM, Musah RA, Bobrowski P, Miller MJ. 2002. Antiinflammatory and antioxidant activities of cat's claw (Uncaria tomentosa and Uncaria guianensis) are independent of their alkaloid content. Phytomedicine 9: 325-337.

Santa Maria A, Lopez A, Diaz MM, Albán J, Galán de Mera A, Vicente Orellana JA, Pozuelo JM. 1997. Evaluation of the toxicity of Uncaria tomentosa by bioassays in vitro. $J$ Ethnopharmacol 57: 183-187.

Santoli D, Zurier RB. 1989. Prostaglandin E precursor fatty acids inhibit human IL-2 production by a prostaglandin Eindependent mechanism. J Immunol 143: 1303-1309.

Schaser J, Bonaterra GA, Kelber O, Weiser D, Kinscherf R, Metz J. 2006. Untersuchung antiinflammatorischer Effekte des Phytopharmakons Phytodolor und seiner Einzelkomponenten in einem Monozyten-Testmodell. Perfusion 19: 76-77.

Schünemann HJ, Oxman AD, Vist GE, Higgins JPT, Deeks JJ, Glasziou P, Guyatt GH. 2008a. Chapter 12: Interpreting results and drawing conclusions. In Cochrane Handbook for Systematic Reviews of Interventions, Higgins JPT, Green S (eds). Wiley-Blackwell: Chichester, UK.

Schünemann HJ, Oxman AD, Higgins JPT, Vist GE, Glasziou P, Guyatt GH. 2008b. Chapter 11: Presenting results and 'Summary of findings tables'. In Cochrane Handbook for Systematic Reviews of Interventions, Higgins JPT, Green S (eds). Wiley-Blackwell: Chichester, UK.

Sethi G, Ahn KS, Pandey MK, Aggarwal BB. 2007. Celastrol, a novel triterpene, potentiates TNF-induced apoptosis and suppresses invasion of tumor cells by inhibiting NFkappaB-regulated gene products and TAK1-mediated NFkappaB activation. Blood 109: 2727-2735.

Sheng Y, Bryngelsson C, Pero RW. 2000. Enhanced DNA repair, immune function and reduced toxicity of C-Med-100, a novel aqueous extract from Uncaria tomentosa. J Ethnopharmacol 69: 115-126.

Siedle B, Gustavsson L, Johansson S, Murillo R, Castro V, Bohlin L, Merfort I. 2003. The effect of sesquiterpene lactones on the release of human neutrophil elastase. Biochem Pharmacol 65: 897-903.

Siemoneit U, Hofmann B, Kather N, Lamkemeyer T, Madlung J, Franke L, Schneider G, Jauch J, Poeckel D, Werz O. 2008. Identification and functional analysis of cyclooxygenase-1 as a molecular target of boswellic acids. Biochem Pharmacol 5: 503-513.

Smolinski AT, Pestka JJ. 2003. Modulation of lipopolysaccharideinduced proinflammatory cytokine production in vitro and in vivo by the herbal constituents apigenin (chamomile), ginsenoside $\mathrm{Rb}(1)$ (ginseng) and parthenolide (feverfew). Food Chem Toxicol 41: 1381-1390.

Song YW, Lee EY, Koh EM, Cha HS, Yoo B, Lee CK, Baek HJ, Kim HA, Suh YI, Kang SW, Lee YJ, Jung HG. 2007. Assessment of comparative pain relief and tolerability of SKI306X compared with celecoxib in patients with rheumatoid arthritis: a 6-week, multicenter, randomized, double-blind, double-dummy, phase III, noninferiority clinical trial. Clin Ther 29: 862-873.
Strehl E, Schneider W, Elstner EF. 1995. Inhibition of dihydrofolate reductase activity by alcoholic extacts from Fraxinus excelsior, Populus tremula and Solidago virgaurea. Arneimittel-Forschung/Drug Res 45: 172-173.

Stoové MA, Andersen MB. 2003. What are we looking at, and how big is it? Phys Ther Sport 4: 93-97.

Sumner H, Salan U, Knight DW, Hoult JR. 1992. Inhibition of 5 -lipoxygenase and cyclo-oxygenase in leukocytes by feverfew. Involvement of sesquiterpene lactones and other components. Biochem Pharmacol 43: 2313-2320.

Takada Y, Ichikawa H, Badmaev V, Aggarwal BB. 2006. Acetyl11-keto-beta-boswellic acid potentiates apoptosis, inhibits invasion, and abolishes osteoclastogenesis by suppressing NF-kappa B and NF-kappa B-regulated gene expression. J Immunology 76: 3127-3140.

Tao XL, Sun Y, Dong Y, Xiao YL, Hu DW, Shi YP, Zhu QL, Dai H, Zhang NZ. 1989. A prospective, controlled, double-blind, crossover study of Tripterygium wilfordii hook F in treatment of rheumatoid arthritis. Chinese Med J 102: 327332.

Tao X, Schulze-Koops H, Ma L, Cai J, Mao Y, Lipsky PE. 1998. Effects of Tripterygium wilfordii hook $\mathrm{F}$ extracts on induction of cyclooxygenase 2 activity and prostaglandin E2 production. Arthritis Rheum 41: 130-138.

Tao X, Younger J, Fan FZ, Wang B, Lipskey PE. 2002. Benefit of an extract of Tripterygium Wilfordii Hook $\mathrm{F}$ in patients with rheumatoid arthritis. Arthritis Rheum 46: 1735-1743.

Tugwell P, Boers M, SImons L, Strand, Wells G. 2004. Evidencebased Rheumatology. BMJ Books: London.

Von Kruedener S, Schneider W, Elstner EF. Elstner EF. 1995. A combination of Populus tremula, Solidage viraurea and Fraxinus excelsior as an anti-inflammatory and antirheumatic drug. Arzneimittel-Forschung/Drug Res 45: 169171.

Wang B, Ma L, Tao X, Lipsky PE. 2004. Triptolide, an active component of the Chinese herbal remedy Tripterygium wilfordii Hook F, inhibits production of nitric oxide by decreasing inducible nitric oxide synthase gene transcription. Arthritis Rheum 50: 2995-2303.

Watson J, Byars ML, McGill P, Kelman AW. 1993. Cytokine and prostaglandin production by monocytes of volunteers and rheumatoid arthritis patients treated with dietary supplements of blackcurrant seed oil. $\mathrm{Br} J$ Rheumatol 32: $1055-1058$.

Wildfeuer A, Neu IS, Safayhi H, Metzger G, Wehrmann M, Vogel U, Ammon HP. 1998. Effects of boswellic acids extracted from a herbal medicine on the biosynthesis of leukotrienes and the course of experimental autoimmune encephalomyelitis. Arzneimittelforsch/Drug Res 48: 668-674.

Williams CA, Harborne JB, Geiger H, Hoult JR. 1999. The flavonoids of Tanacetum parthenium and $\mathrm{T}$. vulgare and their anti-inflammatory properties. Phytochemistry 51: 417423.

Wu H, Ye DJ, Zhao YZ, Wang SL. 1993. Effect of different preprations of ginger on blood coagulation time in mice. Zhongguo Zhon Yao Za Zhi 18: 147-149.

Wurm G, Baumann J, Geres U. 1982. Method for inhibiting cyclooxygenase and inflammation using cherry bioflavonoids [Beeinflussung des Arachidonsäurestoffwechsels durch Flavonoide]. Dtsch Apotheker Ztg 122: 2062-2068.

Ziboh VA, Fletcher MP. 1992. Dose-response effects of dietary gamma-linolenic acid-enriched oils on human polymorphonuclear-neutrophil biosynthesis of leukotriene B4. Am J Clin Nutr 55: 39-45.

Ziboh VA, Naguwa S, Vang K, Wineinger J, Morrissey BM, Watnik M, Gershwin ME.2004. Suppression of leukotriene B4 generation by ex-vivo neutrophils isolated from asthma patients on dietary supplementation with gammalinolenic acid-containing borage oil: possible implication in asthma. Clin Dev Immunol 11: 13-21.

Zhou HF, Niu DB, Xue B, Li FQ, Liu XY, He OH, Wang XH, Wang XM. 2003. Triptolide inhibits TNF-alpha, IL-1 beta and NO production in primary microglial cultures. Neuroreport 14: 1091-1095

Zurier RB, Rossetti RG, Jacobson EW, DeMarco DM, Liu NY, Temming JE, White BM, Laposata M. 1996. Gammalinolenic acid treatment of rheumatoid arthritis. Arthritis Rheum 39: 1808-1817. 